\title{
Evaluating pest-regulating services under conservation agriculture: A case study in snap
}

beans

D. C. Brainard ${ }^{1 *}$, A. Bryant ${ }^{2}$, D. C. Noyes ${ }^{1}$, E. R. Haramoto ${ }^{1,3}$ and Z. Szendrei ${ }^{2}$

${ }^{1}$ Associate Professsor, Technician, and Graduate Student, Department of Horticulture, Michigan

State University, East Lansing, MI; ${ }^{2}$ Graduate Student and Associate Professor, Department of

Entomology, Michigan State University, East Lansing, MI; ${ }^{3}$ Current affiliation: Assistant

Professor, Department of Plant and Soil Sciences, University of Kentucky, Lexington, KY.

*A440A Plant and Soil Sciences Building, East Lansing, MI 48824

email: brainar9@msu.edu phone: 517-355-5191 ext 1417

Although conservation agriculture (CA) practices including strip-tillage (ST) and cover cropping are promoted largely for their potential benefits for soil quality, uncertainty surrounding their short-term effects on pests often constrains adoption. Quantification of ecosystem services or dis-services associated with pests is an important step in identifying research and policy

priorities for improving the performance of CA practices. Beans provide an important source of income and nutrition worldwide and often respond positively to CA practices. However, beans are vulnerable to pest complexes which may be positively or negatively influenced by CA practices. Using insect, weed and yield data from snap beans in a three year vegetable rotation, we estimated the value of pest-regulating services associated with the adoption of CA, and compared it to establishment and management costs associated with implementing CA. Experimental factors included tillage (full-width tillage [FWT] or ST), cover crops (winter rye

1) Brainard et al. 
$[\mathrm{R}]$ or none $[\mathrm{NR}]$ ) and weed management intensity (low or high). The value of pest-regulating services associated with adoption of CA practices was estimated based on pesticide cost savings associated with reductions in pest densities given action thresholds typical of commercial snap bean production systems of the North Central United States. CA practices had no detectable impact on snap bean yields relative to FWT-NR, but resulted in significant tradeoffs in weed and insect abundance. For example, in at least one of two years, ST-R had lower densities of potato leafhopper, Powell amaranth and winter annual weeds, but greater densities of tarnished plant bug and large crabgrass compared to FWT-NR. CA practices had variable effects on natural enemies including ladybeetles, spiders and parasitoids, with no consistent impacts relative to FWT-NR. We estimated that CA practices resulted in net pest-regulating dis-services with costs of \$33 ha $\mathrm{h}^{-1}$ for FWT-R, \$25 ha $\mathrm{har}^{-1}$ for ST-NR, and \$14 ha-1 for ST-R. Under partial adoption of CA (ST-NR), pest-related costs were completely offset by savings in tillage costs, resulting in estimated short-term increases in net returns of $\$ 26 \mathrm{ha}^{-1}$. In contrast, complete adoption of CA (ST-R) resulted in greater pest and cover crop management costs that outweighed savings due to reduced tillage, resulting in estimated short-term losses of $\$ 165 \mathrm{ha}^{-1}$. We conclude that: 1 ) estimates of pest-regulating services based on single species or groups of pests (e.g. insects) may be misleading since they do not account for potential pest tradeoffs (e.g. insects vs weeds); 2) the economic impact of pest-regulating services of CA systems may often be dwarfed by impacts on input costs or savings associated with implementation of those systems, but 3) the value of pest regulation services depends critically on threshold and pest management assumptions. In production systems for which effective, low-cost pesticides are unavailable (e.g. low-income countries) or prohibited (e.g. organic systems), the economic impact of pest regulation services is 
likely to be greater than our estimates suggest. Although CA practices provide several potential long-term ecosystem services at both the farm and landscape level, short-term impacts on pests and yields relative to the costs of implementation are likely to be the major determinant of grower adoption of CA.

\section{Keywords}

Conservation agriculture; reduced tillage; cover cropping; pest-regulation; ecosystem services

3 | Brainard et al. 


\section{Introduction}

Conservation agricultural (CA) practices including reduced tillage (RT), retention of crop or cover crop residues, and crop diversification, have been promoted because of their perceived benefits for soil conservation, profitability, food security and the environment (Hobbs, 2007;

Reicosky, 2015). CA systems are reported to provide multiple ecosystem services including soil moisture retention (e.g. Hendrix et al., 2004), erosion and wind protection for vulnerable soils and crops (e.g. Brainard and Noyes, 2012; Overstreet and Hoyt, 2008), carbon sequestration (Ellert and Janzen, 1999; Reicosky and Linstrom, 1993) and improvements in soil physical, chemical and biological properties (Reicosky, 2015). Despite these wide-ranging potential ecosystem services, adoption of CA practices in many crops has been limited in part due to lack of consistent benefits for crop yield and profitability (Giller et al., 2009; Pittelkow et al., 2015a). In some cases reductions in crop yield under CA practices are due to adverse effects of CA practices on weed, insect or disease pressure which may outweigh benefits for soils (Farooq et al., 2011; Kumar et al., 2013). Since optimization of decision making at both the farm and policy level depends on understanding the net impact of such ecosystem services, more detailed case studies quantifying ecosystem service tradeoffs are needed (Zhang et al. 2007; Pittelkow et al. 2015b).

Beans (Phaseolus vulgaris) —including both snap beans (also known as "green beans") and dry beans - are a critical source of nutrition for much of the world's poor and are grown on approximately 45 million acres worldwide (FAO, 2014). As large-seeded legumes, beans are relatively insensitive to problems of crop establishment and nitrogen deficiency that are 
sometimes associated with RT systems, and therefore represent a promising crop for realization of CA benefits. However, studies evaluating the impact of CA practices on beans show enormous variation in yield responses (Abdul-Baki and Teasdale, 1997; Pittelkow et al., 2015a). Several of these studies have reported responses of individual categories of pests to CA practices (e.g. Bottenberg et al., 1999), but few have attempted to quantify the overall impact of multiple pest responses to CA practices, or the economic implications of these pest-related effects. Weeds represent one of the biggest pest-related constraints to adoption of CA practices. (Brainard et al., 2013; Hoyt et al., 1994; Kumar et al., 2008; NeSmith et al., 1994; Walters and Kindhart, 2002). Indeed, only with the advent of herbicide-resistant crops has adoption of CA practices taken off in many cropping systems (Givens et al., 2009). In RT systems, weed management effects are complex and vary considerably depending on weed species, weed lifestage, edaphic conditions, crop competitive ability, and the availability and effectiveness of alternative weed management strategies (Brainard et al., 2013). In general, RT systems result in lower rates of weed emergence, but higher rates of seedling survival. For example, reduced emergence of weeds under strip-till (ST), compared with full-width tillage (FWT), has been observed for summer annual species in pickling cucumber (Wang and Ngouajio, 2008), carrot (Brainard and Noyes, 2012), and corn (Hendrix et al., 2004). In contrast, weed seedling survival—particularly of winter annual or perennial species—is typically higher under RT systems, since tillage is not used to sever, uproot or bury seedlings (Brainard et al., 2013). The effects of tillage on weeds are further complicated by interactions with crop or cover crop residue that may be present on the soil surface in CA systems (Haramoto and Brainard, 2016). If residues have sufficient biomass to form a thick mulch they may inhibit weed emergence by 
excluding light, providing a physical barrier, or exuding allelochemicals (Teasdale, 1998;

Teasdale and Mohler, 2000). On the other hand, low levels of cover crop residue left on the soil surface may promote weed emergence by creating more favorable edaphic (e.g. higher moisture) conditions for seed germination without inhibiting growth (Brainard et al., 2013; Wallace and Bellinder, 1989). Despite its importance in determining the feasibility of successful adoption of CA systems, the effects of tillage, cover crop and herbicide interactions on weeds have received relatively little attention. For example, Pittelkow et al. (2015a and 2015b) state that the absence of tillage in CA practices involving no-till "generally requires changes in herbicide management", but do not attempt to disentangle herbicide use or weed suppression as factors determining impacts of CA practices on crop yield.

CA effects on insects are also complex and may result in pest-regulating services or disservices depending on the cropping system. Complex habitats, such as untilled strips with cover crop surface mulch, are expected to reduce pest populations by interfering with the movement, landing, and oviposition of pests in the field (Andow, 1988, 1990; Broad et al., 2008; Finch and Collier, 2000). According to the natural enemy hypothesis (Elton, 1958), complex habitats can provide refuge, alternative prey, additional resources, and protection from intraguild predation (Sunderland and Samu, 2000), leading to greater predation and parasitism (Andow, 1988; Landis et al., 2000; Letourneau, 1990; Schellhorn and Sork, 1997; Wilkinson and Landis, 2005). On the other hand, some beneficial insects are well adapted to disturbance (Shearin et al., 2007), and populations of plant pests including slugs (Luna and Staben, 2002), plant-parasitic nematodes (Overstreet et al., 2010), and insect pests such as the imported cabbage worm (Pieris rapae) sometimes increase in CA systems (Bryant et al., 2014). While tradeoffs associated with insect 
management have been discussed in previous work involving some components of CA adoption (Shipanski et al., 2014), few studies have attempted to quantify the economic value of insectregulating services associated with CA.

Although CA practices have several potential long-term economic and environmental benefits, their widespread adoption is likely to depend critically on their short-term impact on profitability due to changes in both yield and input costs. RT is often reported to reduce labor and fuel costs relative to FWT, since fewer tractor passes are required (Archer and Reicosky, 2009; Haramoto, 2014; Luna and Staben, 2002). In contrast, cover cropping generally entails increases in costs associated with establishment and management, as well as opportunity costs in cases where cash crop revenue is forgone in order to accommodate the cover crop (Snapp et al., 2005). Costs of other inputs including herbicides or insecticides may increase or decrease depending on the impact of ST and cover crops on weed and insect pests. Given these important potential tradeoffs, surprisingly few studies have attempted to quantify the net effects of cover crops or tillage on pests or profitability.

A growing body of literature has attempted to value ecosystem services associated with natural pest control, but only a few such studies have addressed monetary values of pest control services at a farm scale, or net effects of multiple pests (e.g. Cleveland et al., 2006; Colloff et al., 2013). Most studies evaluate impacts on a single pest or category of pests (e.g. thrips in Toews et al., 2009 or winter annual weeds in Hayden et al., 2012) and thus provide limited information on potential pest management tradeoffs, and the net effects on pest-regulating services (Zhang et al., 2007). Several reviews have included general discussion of ecosystem services associated with various components of CA practices, including tradeoffs associated with the use of cover crops

7| Brainard et al. 
(Schipanski et al., 2014; Snapp et al., 2005). Among the challenges cited are inherent variability and uncertainty surrounding estimates, and difficulty assessing the relative functional significance of ecosystem service estimates (Schipanski et al., 2014). The cost-avoidance approach (Cleveland et al., 2006, Colloff et al. 2013) partially addresses the latter challenge by quantifying the functional significance of pest-regulating services in monetary terms. Under this approach, the value of pest-regulation of a particular practice is based on the costs (e.g. pesticide costs) and/or revenue losses (due to pest damage) that are avoided when adopting that practice (Cleveland et al., 2006; Colloff et al., 2013).

The primary goal of this study was to estimate the value of pest-regulating services associated with CA practices relative to the short-term costs of implementation of those practices. Specific objectives were to: 1) evaluate the interactive effects of tillage (FWT or ST), cover crops (none or winter rye [Secale cereale]) and weed management intensity (low or high) on weeds, insects, and yields in snap beans; 2) estimate the net value of insect and weed pestregulating services associated with adoption of CA practices; and 3) compare the short-term value of natural pest control under CA practices to the costs associated with implementation. Using insect, weed and yield data from a snap bean field experiment, we illustrate a costavoidance approach for gaining insight into the value of pest-regulation services under CA.

\title{
2. Materials and methods
}

\author{
2.1. Study site
}

8 | Brainard et al. 
This study was conducted from September 2009 through August 2011 (encompassing two growing seasons) in Benton Harbor, MI, USA ( $\left.42^{\circ} 04^{\prime} \mathrm{N}, 86^{\circ} 21^{\prime} \mathrm{W}\right)$, on two adjacent fields at the South West Michigan Research and Extension Center on an Oakville fine sand soil (Mixed, mesic Typic Udipsamment). Three factors, tillage (ST vs FWT), cover crop (none [NR] vs rye $[R]$ ) and weed management intensity (low vs high), were examined in $2 \times 2 \times 2$ factorial, split-split plot design with 4 replications. Tillage was the main plot factor, cover crop the subplot factor, and weed management intensity the sub-sub plot factor. Sub-sub plots measured 3.8 x $9.1 \mathrm{~m}$, with 5 rows of snap beans spaced $76 \mathrm{~cm}$ apart between rows and approximately $7.5 \mathrm{~cm}$ apart in row. Our primary interest was comparison of standard grower practice (FWT-NR) with either partial adoption of CA practices (ST-NR) or full adoption of CA practices (ST-R). Because snap beans were grown in a 3-4 year rotation including sweet corn (Zea mays), cucurbit crops (Cucumis sativus or Cucurbita moschata) and/or fallow, the third component of CA—crop rotation-was not a factor in our experimental design, but rather an integral component of all treatments.

The timing of key field operations and data collection is presented in Table 1. Sweet corn was grown the year before snap beans in both fields. Following harvest in August, the sweet corn crop was mowed and lightly disked and winter rye was drilled into ST-R and FWT-R treatments with a John Deere 750 no-till grain drill (Deere and Company, Moline, IL) at $125 \mathrm{~kg}$ $\mathrm{ha}^{-1}$ on 9 September 2009 and 10 September 2010. In NR treatments, no additional tillage or herbicide management occurred in the fall, and winter annual weeds were allowed to grow. Weeds and cover crops were sprayed with glyphosate $\left(2.24 \mathrm{~kg}\right.$ ai ha $\left.{ }^{-1}\right)$ on 17 May 2010 and 16 
May 2011 to kill existing vegetation. The entire experimental area was flail-mowed on 24 May 2010 and 23 May 2011.

On 25 May 2010 and 1 June 2011, fertilizer was applied across the entire experimental area according to soil test recommendations for snap beans based on soil sampling conducted the previous fall (Warncke et al., 2004), with NPK fertilization levels of 81:100:69 and 78:28:112 kg ha $^{-1}$ in 2010 and 2011 respectively. Tillage was performed immediately after fertilization. In ST treatments, a Hiniker® Model 6000 two-row strip-tiller (equipped with notched row-cleaning discs, cutting-coulter, shank-point assembly, berming disks and rolling basket) was used to create $25 \mathrm{~cm}$ wide x $25 \mathrm{~cm}$ deep strips at $76 \mathrm{~cm}$ between-strip spacing. Therefore, approximately $67 \%$ of the soil surface was left undisturbed in the ST systems, with either rye residue (ST-R) or winter annual weed residue (ST-NR) present on the soil surface between strips. FWT tillage was accomplished with a moldboard plow followed by two passes with tandem disks and one pass with a field cultivator.

Snap bean 'Provider' was planted in tilled strips on 26 May 2010 and 2 June 2011 using a MaterMac Series 8000 two-row vacuum precision planter. For weed management, the entire experimental area received a combination of S-metolachlor pre-emergence at $1.06 \mathrm{~kg}^{\mathrm{ai} \mathrm{ha}}{ }^{-1}$, and clethodim at $0.076 \mathrm{~kg}$ ai ha ${ }^{-1} 35$ days after planting (DAP). "High intensity" weed management treatments received an additional application of bentazon at $0.84 \mathrm{~kg}$ ai ha $\mathrm{ha}^{-1} 27-29 \mathrm{DAP}$. No fungicide or insecticide applications were made during the two growing seasons. Harvest occurred on 19 July 2010 and 26 July 2011.

\subsection{Data collection}

10 | Brainard et al. 
On 29 April 2010 and 10 May 2011, winter annual weeds were counted by species from two $0.25 \mathrm{~m}^{2}$ quadrats per plot. Rye and weeds were then clipped at ground level, placed into paper bags, dried at $60^{\circ} \mathrm{C}$ and weighed. To evaluate the effects of tillage and cover crops on emergence of summer annual weeds, approximately 600 seeds of common lambsquarters (Chenopodium album) and approximately 700 seeds of Powell amaranth (Amaranthus powellii) were sown in separate $0.25 \mathrm{~m}^{2}$ quadrats in the between row zone of low weed management intensity plots. Emergence of weeds was evaluated on 21 June 2010 and 16 June 2011 by counting all individuals by species from these sown areas. Included in these counts were both sown species, as well as weeds emerging from the ambient seedbank, including primarily large crabgrass (Digitaria sanguinalis), which was abundant in both years. The final density and composition of weeds in the snap bean crop was evaluated by counting, by species the number of weeds taller than the crop canopy (overtopping weeds) on 19 July 2010 and 26 July 2011 from a $20 \mathrm{~m}^{2}$ area in the center of each plot. Counts were conducted separately for the between-row and in-row zones. In snap bean fields dominated by summer annual weeds, the number of weeds overtopping the crop canopy is highly correlated with weed biomass, and provides a more efficient method of evaluating treatment effects on economically relevant levels of weed infestation (Brainard unpublished).

Arthropod herbivores were evaluated by visually sampling all the leaves of 10 randomly selected plants per plot during the life of the bean plants. Natural enemies, due to their mobility, were sampled with yellow sticky cards $(7.6 \mathrm{~cm}$ wide x $12.7 \mathrm{~cm}$ long, Great Lakes IPM, Vestaburg, MI, USA). One yellow card was placed at canopy level in the center of each sampled

11 | Brainard et al. 
plot; sticky cards were removed for counting and replaced with fresh cards on the same day. Three samples (both visual and trap) were taken in 2010 on 1 July, 7 July and 16 July. In 2011 weekly sampling occurred between 16 June and 26 July, for a total of 7 sampling dates. The total number of arthropods, identified to order, family or species. Arthropods were sampled only from high weed management intensity plots with the two types of tillage and cover crop management treatments (4 treatments).

At harvest, twelve row-meters of snap beans from two of the center rows from each plot were clipped at soil level and weighed. Pods were removed by hand and weighed. A harvest index was calculated by dividing pod weight by total aboveground plant weight for each treatment. Pods from a $500 \mathrm{~g}$ subsample from each plot were visually assessed and rated for insect damage and other defects. Roots were also inspected for signs of root rot pathogens, with none detected, so no further quantification was conducted.

\subsection{Statistical analysis}

The fixed effects of tillage, cover crop and weed management intensity on bean yield, harvest index and weed density were evaluated using the PROC Mixed procedures of SAS (SAS, 2014), with block (replicate) treated as a random effect. All responses were analyzed separately by year as initial testing indicated significant zone by treatment and year by treatment interactions. Weed responses in the in-row and between-row zones were analyzed separately. Since weed emergence and insect responses were evaluated for only one weed management intensity level, only the fixed effects of tillage and cover crops were assessed for these responses. Winter

12 | Brainard et al. 
annual weed counts and biomass were evaluated prior to implementation of tillage and weed management intensity treatments, therefore only the fixed effect of cover crop was evaluated, with replicate and year treated as random effects. For arthropods, the response variable was mean density across all sampling dates. For tarnished plant bug (Lygus lineolaris) in 2010, and potato leafhopper (Empoasca fabae) in 2011, additional analysis was conducted at each individual sampling date in order to assess densities relative to published action threshold recommendations. For both weed and insect densities, data were log or square-root transformed as necessary to improve assumptions of normality and equal variance of population distributions.

\subsection{Estimation of economic value of pest-regulating services and total input costs}

2.4.1. Cost avoidance methodology. In order to estimate the costs and benefits associated with pest-regulation services associated with CA practices, we followed a cost-avoidance approach in which the value of pest-regulation is based on the costs that are avoided when adopting practices which provide natural pest control (Cleveland et al., 2006; Colloff et al. 2013). These avoided costs may include the value of the crop that would have been lost due to pests in the absence of adoption of CA, as well as reduced pesticide costs attributable to reduced pest abundance under CA (Cleveland et al., 2006; Colloff et al., 2013). We did not attempt to quantify changes in social and environmental costs associated with different levels of pesticide use, although others have included such estimates in their analyses (Cleveland et al., 2006; Kovach, 2003; Pimentel et al., 1991)

Changes in pesticide costs (including both the pesticide itself and application costs) associated with CA adoption can be calculated based on pest densities relative to estimated 
action thresholds (Cleveland et al. 2006). In our case, we assessed impacts of CA practices on the density of multiple insect and weed pests. For each insect or weed observed in our field study, we compared densities in each alternative treatment (Da) with their density in the FWTNR control treatment $(\mathrm{Dc})$. For pests whose densities were influenced by treatment in at least one year of our field study $(\mathrm{Da} \neq \mathrm{Dc}$ ), we considered four outcomes (O1-O4), representing four possible relationships between the density of pest in the control and alternative treatments and specific published action threshold estimates (Dt):

O1: Da $<\mathrm{Dt}$ and $\mathrm{Dc}<\mathrm{Dt}$ (Pest density below threshold in both treatments)

O2: $\mathrm{Da}<\mathrm{Dt}$ and $\mathrm{Dc}>\mathrm{Dt}$ (Pest density below threshold only in the alternative treatment)

O3: $\mathrm{Da}>\mathrm{Dt}$ and $\mathrm{Dc}<\mathrm{Dt}$ (Pest density below threshold only in the control treatment)

O4: $\mathrm{Da}>\mathrm{Dt}$ and $\mathrm{Dc}>\mathrm{Dt}$ (Pest density above threshold in both treatments)

We assumed that pesticides would be applied if and only if pest densities exceeded the action threshold and therefore that differences in pesticide use between the alternative and control treatments would only occur if observed densities exceeded the threshold in one treatment but not the other $(\mathrm{O} 2$ or $\mathrm{O} 3)$. Under this assumption, the expected pesticide cost saving associated with the alternative treatment (Sa) for a specific pest was calculated according to:

(1) $\mathrm{Sa}=\mathrm{P}_{2} * \mathrm{Cp}-\mathrm{P}_{3} * \mathrm{Cp}-\mathrm{AC}$

14 | Brainard et al. 
where $\mathrm{P}_{2}$ is the probability of $\mathrm{O} 2 ; \mathrm{P}_{3}$ is the probability of $\mathrm{O} 3$; and $\mathrm{Cp}$ is the cost of the pesticide used to control the pest (price of pesticide times the quantity used) and AC is the application cost.

Based on our assumptions regarding action thresholds (Table A.1 and Section 2.4.2), and observed pest densities in our field studies, we assigned probabilities for each outcome $\left(\mathrm{P}_{2}\right.$ and $\mathrm{P}_{3}$ in equation 1) of either $0,0.5$ or 1 (Table A.2). A probability of 0.5 for a given outcome indicated that it occurred in one of two years, while a probability of 1 indicated that outcome occurred in both years. The values of total pest management services were then calculated by summing the estimated changes in pesticide costs of each weed and insect pest from Equation 1.

2.4.2. Action threshold assumptions. Action threshold estimates were based on information from published studies and grower guides (Table A.1). For large crabgrass, our threshold estimate was based on the work of Aguyoh and Masiunas (2003a), who found that snap bean yield was reduced by between 10 and $60 \%$, and that large crabgrass was capable of producing between 1,000 and 3,000 seeds per plant depending on the density and time of emergence relative to the snap bean crop. They concluded that infestations of greater than two plants per m-row (approximately eight plants $\mathrm{m}^{-2}$ ), should be controlled to avoid yield loss and seed production. Thresholds for broadleaf weeds were based on Aguyoh and Masiunas (2003b) and Harrison (1990) whose studies suggest that densities of species such as redroot pigweed (Amaranthus retroflexus, a close relative of Powell amaranth) and common lambsquarters of as little as 0.5 - 2 per $\mathrm{m}$ row (approximately 2-4 plants $\mathrm{m}^{-2}$ ) can reduce yield, interfere with harvest efficiency or produce sufficient seeds to justify herbicide application. No published thresholds are available 
for winter annual weeds prior to snap bean production, but we utilized personal observations to inform our assumption that biomass of greater than $100 \mathrm{~g} \mathrm{~m}^{-2}$ would trigger spring herbicide applications. Although winter annual weeds can provide valuable ecosystem services such as erosion control and recycling of residual nutrients (Jordan and Vatovec, 2004), their net impact in early spring is generally perceived by growers as negative, since they can interfere with crop establishment, reduce yields, and host insect and disease pests (Norris and Kogan, 2005; Wisler and Norris, 2005). If seed production of these species is not prevented, winter annuals can reduce yields and contaminate rotational crops including peas (Ogg et al., 1993) and wheat (Conley and Bradley, 2005).

Assumptions for insect pest thresholds were based on a variety of studies and pest management guides used by growers in the North Central US (Table A.1). For potato leaf hopper, thresholds are variously reported as one nymph per 10 leaves (Delahaut, 2005), or 16 per m of row (Cook et al., 2004). Given our plant density and bean leaf number, these thresholds translate into approximately 1-1.5 nymphs per plant at later growth stages. Threshold densities for tarnished plant bug and aphids (superfamily Aphidoidea) were assumed to be 0.2 insects per plant and 1.0 per leaf, respectively, based on the reported ranges in Bird et al. (2014) and yield loss data from Khattat and Stewart (1975) and Stewart and Khattat (1980).

2.4.3 Input cost estimates. Assumed changes in costs directly associated with tillage and rye cover cropping were based on custom machine work rates from Stein (2011) for moldboard plowing, strip tillage, disking, harrowing, planting, mowing and pesticide application. Costs for rye seed, herbicides and insecticides were estimated based on price lists from local dealers,

16 I Brainard et al. 
combined with recommended use rates from grower guides (Zandstra, 2011; Bird et al., 2011). Details of these assumptions are provided in Table A.1 and Table 7.

3. Results and Discussion

\subsection{Rye cover crop and winter annual weeds}

At the time of glyphosate application in the spring, rye shoot dry weight was $530 \mathrm{~g} \mathrm{~m}^{-2}$ in 2010, and $380 \mathrm{~g} \mathrm{~m}^{-2}$ in 2011 (Fig. 1). Winter annual weed dry weight in non-cover crop treatments at this time was $100 \mathrm{~g} \mathrm{~m}^{-2}$ in 2010 and $240 \mathrm{~g} \mathrm{~m}^{-2}$ in 2011 ; thus rye reduced the dry weight of winter annual weeds by $90 \%$ in 2010 , and $67 \%$ in 2011 . The most abundant winter annuals were common chickweed (Stellaria media), henbit (Lamium amplexicaule), purple deadnettle (Lamium purpureum) and mouse-ear cress (Arabidopsis thaliana) in 2010, and knawel (Scleranthus annus) in 2011 (Table 2). The presence of rye reduced the density of henbit, purple deadnettle and mouse-ear cress, but not common chickweed or knawel.

The level of suppression of winter annual weed biomass by rye in this study was lower than the $95-98 \%$ reported by Hayden et al. (2012), despite similar levels of rye biomass accumulation (300-600 $\mathrm{g} \mathrm{m}^{-2}$ ). This discrepancy may have been due in part to a different community of winter annual weeds. Hayden et al. (2012) reported that rye generally suppressed mustard family weeds more than non-mustards. With the exception of mouse-ear cress - a relatively small mustard family weed - all winter annuals in this study were non-mustards. 


\subsection{Summer annual weeds}

3.2.1. Emergence. Emergence of both common lambsquarters and large crabgrass was affected by tillage or tillage by cover crop interactions (Table 3). In contrast, the emergence of Powell amaranth was not affected by tillage, cover crops or their interaction in either year. For common lambsquarters, the effect of tillage depended on whether or not rye was present (significant tillage by cover crop interaction). In particular, common lambsquarters emergence was reduced by approximately $80 \%$ in 2010 and 57\% in 2011 in ST-R compared to either ST-NR or FWT. For large crabgrass, no effects of treatment on emergence were detected in 2010, likely due to large variability in crabgrass density. In 2011, large crabgrass emergence was higher in ST, and ranked as follows from lowest to highest: FWT-NR $<$ FWT-R $=$ ST-R $<$ ST-NR. In other words, the presence of rye suppressed emergence of large crabgrass within the ST system, but stimulated emergence when FWT was used.

Such suppression of weed emergence from rye surface mulch has been previously observed in many studies, and was likely the result of a combination of physical and chemical properties of rye mulch (Teasdale and Mohler, 2000). More surprising was the apparent promotion of large crabgrass emergence in the presence of rye under FWT in 2011. This effect may have been the result of reduced efficacy of S-metolachlor in the presence of incorporated rye. Crop and cover crop residues may reduce the efficacy of chloroacetamides, including Smetolachlor through interception or adsorption (Banks and Robinson, 1986; Locke and Bryson, 1997). Although this effect might have been expected to be higher under ST with rye surface

18| Brainard et al. 
mulch, any reduction in herbicide efficacy from surface rye may have been outweighed by the allelopathic or physical suppressive effects of rye mulch.

3.2.2. Final weed density. In 2010, the final density of common lambsquarters and Powell amaranth individuals that were taller than the bean crop canopy at harvest was not affected by tillage, cover crop, or weed management intensity (Table 4). However, large crabgrass densities in the crop row were higher under ST compared to FWT, and higher in rye treatments compared to non-rye treatments. In 2011, weed management intensity influenced the final density of both common lambsquarters and Powell amaranth; not surprisingly, lower densities of both species were present in high compared to low intensity weed management treatments. Tillage and cover crop factors also influenced final weed density in 2011 in some cases. In particular, large crabgrass final density in the crop row was almost four times higher under ST compared to FWT. In 2011, Powell amaranth final density between crop rows was suppressed by rye, regardless of tillage system. However, no effects of tillage or cover crops on final common lambsquarters density were detected in either year or location.

\subsection{Insects}

Tillage influenced the number of potato leafhoppers in 2011, but had no detectable effect on other insect pests including tarnished plant bug, aphids or thrips (order Thysanoptera) in either year (Table 5). In 2011, ST treatments had 31\% fewer potato leafhoppers than FWT

(Table 5; Fig. 2). Contrary to expectations, ST in combination with rye surface residue resulted 
in reductions in beneficial lady beetles (Coccinellidae) and parasitoids in 2010, although these effects were not observed in 2011.

In 2010, the presence of a rye cover crop resulted in a 4-fold increase in tarnished plant bug density and a 2.5 -fold increase in aphid density, but had no detectable effect on other insect pests or beneficials (Table 5). In 2011, rye had no detectable effect on insect pests, but resulted in an increase in lady beetle abundance and a decrease in spider (Araneae) abundance relative to non-rye treatments. It is likely that our small plot size may have been limiting in capturing consistent treatment effects on mobile arthropods, such as lady beetles and spiders, since these can easily move among experimental plots.

Such inconsistent impacts of RT on specific insect pests and beneficials have been reported in previous studies (Bryant et al., 2014; Luna and Staben, 2002; Overstreet et al., 2010; Shearin et al., 2007). The use of grass family cover crops in the absence of RT systems can exacerbate insect pests including several lepidopteran species in corn based systems (Schipanski et al., 2014), but had minimal effects on insect pests in a broccoli cropping system (Wyland et al. 1996). In snap beans, Bottenberg et al. (1999) observed a reduction in potato leafhopper abundance under no-till with a rye surface mulch compared to FWT, but because yields were also reduced, it is unclear whether this effect was the direct result of CA practices, or an indirect effect of crop quality.

3.4 Crop yield and harvest index.

20 | Brainard et al. 
Snap bean yield was not affected by tillage, cover crop, weed management intensity nor their interactions in either year (Table 6). Mean bean yields were 5.01 $\mathrm{T} \mathrm{ha}^{-1}$ in 2010 and 5.16 T/ha in 2011, compared to MI statewide averages for fresh snap beans of $5.05 \mathrm{ha}^{-1}$ and $6.18 \mathrm{ha}^{-1}$ in 2010 and 2011 respectively. Bean harvest index (pod weight divided by total plant weight $\mathrm{x}$ 100) was also unaffected by treatments with mean values of $42.7 \%$ in 2010 and $33.7 \%$ in 2011. The lack of detectable treatment effects on snap bean yield and harvest index suggest that the observed impacts of tillage and cover crops on both insect pests and natural enemies in our study were not the result of indirect effects on crop size or above ground carbon-partitioning.

It should be noted that a lack of detectable treatment effects on yield does not imply that weed or insect pests did not have a negative effect on yield, nor that growers would not be justified in managing these pests. Crop yield is likely to be influenced both by pests, and by changes in edaphic conditions that are often influenced by CA practices. For example, benefits associated with improved moisture retention in ST systems (Haramoto and Brainard, 2012; Hendrix et al., 2004) may offset costs associated with insects or weeds, resulting in nondetectable yield effects. Moreover, management of pests may be justified based on potential negative impacts unrelated to yield. For example, weeds that have no impact on yield may host disease or insect pests or produce seeds that are detrimental to future crops.

Previous studies have reported improved yields and/or profitability of ST relative to both no tillage (NT) or FWT in many crops (Hoyt et al., 1996; Lonsbary et al., 2004; Luna and Staben, 2002; Luna et al., 2012; Mochizuki et al., 2007; Mochizuki et al., 2008; Wang and Ngouajio, 2008), although reductions in crop yields in ST compared to FWT have been observed in some cases (Bryant et al., 2013; Hoyt, 1999). In snap beans, yield responses to tillage have 
been variable. For example, Bottenberg et al. (1999) found that yields under ST were improved relative to NT, but lower compared to FWT in some years. In contrast, Abdul-Baki and Teasdale (1997) reported improvements in snap bean yields under NT with cover crop residue compared to FWT without residue. Based on a meta-analysis of 166 studies evaluating the impact of CA practices on yields of legumes (including beans), Pittelkow et al. (2015b) reported large variability in yield responses, with a tendency towards improved yields occurring only under dry, rainfed conditions. The same analysis applied to the subset of 26 studies involving only beans gave similar results, with no overall yield response to CA practices detected, and responses varying widely across production zones (Pittelkow, personal communication). However, it should be noted that Pittelkow et al. (2015a) included paired comparisons of CA vs non-CA treatments which also differed in their herbicide use, so it is unclear whether yield differences were due to CA practices per se, or differences in weed management across these systems.

\subsection{Pest-Regulating Services}

3.5.1. Rye cover cropping. Relative to standard practice of not using a cover crop, the inclusion of a rye cover crop in snap bean production under conventional full-width tillage (FWT-R) resulted in an estimated total pest-regulating dis-service of $\$ 32.7 \mathrm{ha}^{-1}$ due to higher costs associated with management of large crabgrass and tarnished plant bug (Table 7). For large crabgrass, we estimated a cost of $\$ 14.1$ ha $^{-1}$ associated with FWT-R compared to FWT-NR based on an observed increase in density in one of two years (Table 3) that was sufficient to require an additional pesticide application based on our threshold assumptions (Outcome 3; Tables A.1 and 
A.2). Similarly, for tarnished plant bug we estimated a cost of $\$ 18.6 \mathrm{ha}^{-1}$, based on an observed increase in density in FWT-R compared to FWT-NR in one of two years (Table 5; Fig. 3), that was sufficient to require an additional pesticide application (Outcome 3; Tables A.1 and A.2). For all other weed and insect pests, FWT-R either had no effect, or did not influence densities sufficiently to result in either pesticide costs or savings compared to FWT-NR given our threshold assumptions (Outcomes 1 or 4 ).

The estimated impacts of rye cover cropping on pest regulating services in our study contrast to some extent with previous studies. For example, in FWT corn-soybean-wheat cropping systems, Schipanski et al. (2014) estimated — based on model simulations and "expert opinion"- that an incorporated rye cover would suppress spring weeds by $24 \%$, and summer weeds in subsequent crops by $14 \%$. They concluded that these effects constituted a pestregulating ecosystem service, although no information is provided on whether these reductions in weed density would actually improve yield or reduce weed management costs. With respect to insects, Schipanski et al. (2014) noted that rye cover cropping exacerbated important lepidopteran pests in corn-soybean cropping systems, but did not consider this effect strong enough to constitute an ecosystem dis-service, given potential positive effects on beneficial insects.

When compared to the considerable costs associated with establishment and maintenance of rye, we found that pest regulating effects were small (Table 7). In particular, we estimated that the cost associated with rye cover cropping in the FWT system was approximately $\$ 199 \mathrm{ha}^{-1}$. This total estimate included costs associated with planting and terminating rye (\$172), as well as the costs associated with incorporating rye following termination (\$27). When combined with 
the estimated economic cost of pest management dis-services associated with rye, this system resulted in a net short-term economic loss of $\$ 232 \mathrm{ha}^{-1}$. Our estimate of the costs associated with rye cover cropping are almost identical to those of Schipanski et al. (2014), although their estimate excluded costs associated with termination of rye. Wyland et al. (1996) estimated that the cost of rye cover cropping represented $5 \%$ of the costs required to produce a broccoli crop. However, their estimate did not include seed costs, and no dollar value was provided.

3.5.2. Strip-tillage. Partial adoption of CA practices in the form of strip tillage alone (ST-NR) resulted in estimated total pest-regulating dis-service of $\$ 25.3 \mathrm{ha}^{-1}$ due to higher costs associated with management of winter annual weeds and large crabgrass, which more than offset the estimated cost-savings associated with reduced potato leafhopper densities (Table 7). For winter annual weeds, we estimated a pesticide cost of $\$ 29.9 \mathrm{ha}^{-1}$ associated with ST-NR compared to FWT-NR based on an observed increase in biomass in both years (Fig. 1) that was sufficient to require an additional pesticide application based on our threshold assumptions (Outcome 3; Tables A.1 and A.2). Under FWT-NR, winter annual weeds also exceeded thresholds, but would not require a pesticide application because spring tillage operations were assumed to provide sufficient suppression. For large crabgrass management, we estimated a pesticide cost of \$14.1 ha ${ }^{-1}$ associated with ST-NR compared to FWT-NR based on higher emergence observed in one of two years (Table 3), warranting an additional pesticide application given our threshold assumptions (Outcome 3; Tables A.1 and A.2). In contrast, for potato leafhopper, we estimated a pesticide cost savings of $\$ 18.6 \mathrm{ha}^{-1}$ based on an observed reduction in ST-NR compared to FWT-NR in one of two years (Fig. 2) that saved a pesticide application (Outcome 2; Tables A.1

24 | Brainard et al. 
and A.2). For all other weed and insect pests, ST-NR either had no effect, or did not influence densities sufficiently to result in either pesticide costs or savings compared to FWT-NR (Outcomes 1 or 4 ).

To our knowledge, no previous studies have attempted to quantify the value or cost of the pest regulating-impacts of strip tillage. Previous studies documented differences in abundance of weeds (Brainard and Noyes, 2012; Hendrix et al., 2004; Wang and Ngouajio, 2008) or insects (Bryant et al., 2014; Overstreet et al., 2010) associated with strip tillage, but did not compare these densities to action thresholds to estimate their likely economic impact.

In contrast to rye cover cropping, ST resulted in tillage-related cost savings compared to FWT-NR that outweighed costs associated with pest-regulating dis-services (Table 7). Tillage cost savings were estimated at $\$ 51.2 \mathrm{ha}^{-1}$ due to elimination of plowing, disking and harrowing operations which were greater than the cost associated with strip tillage (Table 7). These estimates are consistent with previous studies in which estimated tillage cost savings associated with ST ranged from \$20 to 84 ha $^{-1}$ (Archer and Reicosky, 2009; Haramoto, 2014; Luna and Staben, 2002) depending on assumptions regarding scale of equipment, purchasing price, fuel requirements, labor costs, interest rates, and the number of tillage operations in the FWT control. Taking both tillage and pesticide costs into account, the overall short-term cost savings of STNR compared to FWT-NR in our study was estimated at $\$ 25.8 \mathrm{ha}^{-1}$ (Table 7).

3.5.3. Strip tillage and rye cover cropping. Full adoption of CA practices (ST-R) was estimated to result in a pest-regulating dis-service with an estimated cost of $\$ 14.1 \mathrm{ha}^{-1}$ compared to FWTNR. This overall pest-regulating dis-service was due to increased costs associated with 
management of large crabgrass and tarnished plant bug, which offset savings associated with lower densities of potato leafhopper (Table 7). For large crabgrass, densities in ST-R increased relative to FWT-NR in one of two years (Table 3), and the increase was sufficient to require an additional pesticide application based on our threshold assumptions (Outcome 3; Tables A.1 and A.2), with an estimated expected cost of $\$ 14.1 \mathrm{ha}^{-1}$. For tarnished plant bug, densities in ST-R were higher than those in FWT-NR in one of two years (Table 5; Fig. 3), and sufficiently high to require an additional pesticide application based on our threshold assumptions (Outcome 3; Tables A.1 and A.2) with an estimated cost of $\$ 18.6 \mathrm{ha}^{-1}$. In contrast, ST-R resulted in a reduction in potato leafhopper densities (Table 5; Fig. 2), resulting in a savings of $\$ 18.6$ ha $^{-1}$ associated with pesticide avoidance (Outcome 2; Table A.1 and A.2).

For all other weed and insect pests, ST-R either had no effect, or did not influence densities sufficiently to result in either pesticide costs or savings compared to FWT-NR under our threshold assumptions (Outcomes 1 or 4; Table A.2). For example, although ST-R resulted in a reduction of common lambsquarters emergence in both years (Table 3), the resulting densities remained greater than the estimated action threshold (Table A.1), so did not result in any pesticide avoidance (Outcome 4; Table A.2). Similarly, rye suppressed winter annual weeds compared to FWT-NR, but did not result in pesticide avoidance since tillage was assumed to manage these weed species (Outcome 1; Table A.2).

When compared to the costs associated with establishment and maintenance of rye, the impact of pest regulating effects of ST-R were small (Table 7). Cover crop costs exceeded cost savings associated with tillage. Overall, we estimated that complete adoption of CA practices (ST-R) increased short-term management costs by $\$ 165$ ha $^{-1}$ compared to FWT-NR, with pest 
regulating effects accounting for less than $10 \%$ of these costs. Thus, complete adoption of CA practices in snap beans did not provide sufficient synergistic benefits for pest-regulation to improve short-term economic performance relative to adoption of strip tillage alone.

\subsection{Implications beyond North Central US production systems.}

3.6.1. Impacts of CA in absence of pesticides. It is important to note that our estimates of the value (or cost) of pest-regulating services (or dis-services) are based on two major sets of assumptions: 1) the pesticides listed in Table A.1 are highly effective at managing their associated pests, and available to growers at the specified price; and 2) that the use of these pesticides is based on observed pest densities in relation to action thresholds. Although we believe these assumptions are reasonable for snap bean production regions of the North Central US, they have more limited applicability in regions and cropping systems for which pesticides are unavailable, prohibited, or limited in effectiveness. In such cases it is likely that observed differences in pest density associated with CA practices will have a larger impact on costs or crop yields then our pesticide-based estimates might suggest.

To illustrate how the value of pest regulation of CA practices might differ in systems without pesticide use, published estimates of changes in yield associated with differences in pest density are helpful. In the absence of pesticides, increases in pest density are likely to result in either increased costs associated with non-chemical management (e.g. hand weeding) or losses in

yield and revenue due to the pest, or both. For example, based on estimates of yield losses due to large crabgrass (Aguyoh and Masiunas, 2003a) and our emergence data from 2011 (Table 3), growers without herbicides would either need to rely on cultivation and hand weeding to reduce

27 | Brainard et al. 
densities or face yield losses of 30-50\%. Gianessi and Reigner (2007) estimated without herbicides, at least 30 hours ha ${ }^{-1}$ of hand weeding and two cultivation passes would typically be used to manage weeds in snap beans, and that yield losses of $20 \%$ would still occur due to weed escapes. Under these circumstances, the costs associated with higher crabgrass density under ST would likely far exceed the $\$ 14.1 \mathrm{ha}^{-1}$ associated with herbicide applications in our pesticidebased estimates.

Similarly, in the absence of insecticides, the impact of insect-regulating effects of CA are likely to increase substantially. For example, using yield loss data associated with varying densities of tarnished plant bug from Khattat and Stewart (1975) we estimate that higher densities of this insect associated with rye cover cropping in our study (Fig. 3) would result in yield losses of approximately 5\% compared to FWT-NR in the absence of control measures. Given typical bean prices and yields for the North Central US (Ho et al., 2011), this yield loss equates to approximately $\$ 50-135 \mathrm{ha}^{-1}$. In contrast, based on potato leafhopper effects on yields reported in Wisconsin (US) snap bean studies (Gonzalez and Wyman, 1991), reductions in potato leafhopper density observed under ST in our study (Fig. 2), might be expected to result in improvements in yields of between 0 and 50\% depending on the year, planting timing, and snap bean cultivar. Assuming an intermediate yield improvement of 25\%, and typical snap bean prices and yields for the North Central US (Ho et al., 2011), the value of suppression of potato leafhopper under ST in the absence of insecticides would be approximately $\$ 250-675 \mathrm{ha}^{-1}$.

These examples suggest that when pesticides are not available, adoption of rye cover cropping appears less attractive then when pesticides are available, since observed pest effects were primarily negative with rye, and since more expensive control options would be required to

28 | Brainard et al. 
address them. In contrast, in the absence of pesticides, the economic impact of complete adoption of CA (ST-R) is more difficult to predict, since cost avoidance associated with reduced potato leafhopper and common lambsquarters densities might outweigh the increased costs associated with large crabgrass control.

3.6.2. Importance of pest communities. Because CA practices have variable effects on specific pests, the composition and relative abundance of weed, insect, and disease communities will clearly have an important impact on pest regulation services associated with CA. The pests observed in our field study are ubiquitous in the North Central bean production systems, but their relative importance varies both spatially and temporally depending on climate and cropping system. For example, potato leafhopper abundance varies substantially from year to year in North Central bean production systems (Gonzalez and Wyman, 1991). Therefore, the potential benefits associated with natural control of this pest under ST will also vary. Pest complexes in beans in other parts of the world may also be very different from those found in the North Central US (e.g. Abate et al., 1996), and will likely entail distinct pest-regulating tradeoffs with different net short-term impacts than those evaluated in our study. Finally, it should be noted that in our trials, we did not observe any effects of CA on plant diseases, but pathogens can be a major problem in beans production systems worldwide (e.g. Naseri and Mousavi, 2015), and may be either exacerbated or suppressed under CA practices (Page et al., 2013).

3.6.3. Implications of alternative price and yield assumptions. To put our estimates in economic perspective, it is useful to consider the yield increases that would be required to offset costs associated with rye cover cropping, and how they might vary under different production systems and markets. For example, to offset the estimated cost of full adoption of CA (ST-R) in

29| Brainard et al. 
processing snap beans in the North Central US, yield increases of 5-15\% would be required given typical yields (5-9 $\left.\mathrm{T} \mathrm{ha}^{-1}\right)$ and prices $\left(\$ 200-300 \mathrm{~T}^{-1}\right)$ provided in Ho et al. (2011). In contrast, yield increases of as little as $2-4 \%$ would be required for fresh market snap beans, since they typically have prices 4-5 times greater than processing beans (ERS, 2011).

Although we observed no yield impacts associated with CA practices in our study, other studies have shown either yield reductions (Bottenberg et al., 1999) or improvements (AbdulBaki and Teasdale, 1997) in response to CA practices in beans in US cropping systems. Similarly variable responses have been reported in studies from around the world (Pittelkow et al. 2015a). Depending on bean prices and input costs associated with bean production in different production areas, yield improvements in response to CA practices may justify adoption of CA even if pest effects and costs associated with residue retention are similar to those observed in our study.

\section{Summary and Conclusions}

Our study evaluated the short-term impact on yields, pests, and costs of CA practices (reduced tillage and residue retention) compared to standard grower practices in snap bean production systems typical of the North Central US. Overall, we found that CA practices had (i) no effect on yields; (ii) significant effects on the abundance of economically important insects (e.g. tarnished plant bug and potato leafhopper) and weeds (e.g. large crabgrass, Powell amaranth); but (iii) the estimated net economic impact of these pest effects was relatively small in comparison to the costs of establishment and maintenance of cover crops.

30 | Brainard et al. 
Overall, our results suggest that partial adoption of CA practice in the form of reduced tillage (ST-NR) is likely to have immediate economic benefits for snap bean growers (Table 7). Yields under ST were comparable to those under FWT-NR, while savings in input costs were estimated to be $\$ 24 \mathrm{ha}^{-1}$ due to reductions in tillage and insecticide costs which outweighed increased herbicide costs. Therefore, the potential risks associated with increasing weed density under ST appear to be low for commercial snap bean producers, while potential short-term benefits are substantial. In contrast, we estimated that rye cover cropping alone (FWT-R) or in combination with strip tillage (ST-R) would result in short-term reductions in profitability for snap bean producers of more than $\$ 150 \mathrm{ha}^{-1}$ due to seed and maintenance costs that outweigh impacts associated with weed and insect pests (Table 7).

Although our study provides a useful approximation of the short-term impact of CA practices on pests and profits for snap bean production in the North Central US, we caution that our results have limited applicability to cropping systems with restricted access to pesticides, different pest complexes, and different relative input costs. In particular, pest-regulating effects of CA are likely to take on greater importance in cropping systems and regions in which pesticide use is limited. In such systems, the costs of pest-regulating dis-services observed in our study would likely increase substantially depending on the cost and effectiveness of alternative pest management practices, and the impact on yields (and profits) of pests escaping those management practices (see Section 3.6.1). Overall, we speculate that grower incentives for adopting CA practices may be lower in these alternative systems, given their general tendency to exacerbate pest problems.

31 | Brainard et al. 
Although pest regulating services and dis-services are often extremely important in explaining grower adoption or dis-adoption of CA practices (Farooq and Siddique, 2015; Neill and Lee, 2001), they must be viewed in the larger context of wide-ranging ecosystem service tradeoffs (Zhang et al., 2007). In some cases, non-pest-regulating ecosystem services of CA may overshadow pest effects. For example, soil moisture retention may be a particularly critical service provided by CA practices in regions with limited rainfall or access to irrigation, resulting in yield improvements for crops (Pittelkow et al., 2015b) that outweigh costs associated with pests and CA implementation. Similarly, reduced tillage and cover cropping practices may protect soils and crops from extreme weather events and enhance soil physical and biological properties that ultimately improve yields (Hobbs, 2007; Palm et al., 2014; Snapp et al., 2005). Although documented yield benefits from non-legume cover crops-including cereal rye-are often small or absent in the short term, longer term increases in soil organic matter or reductions in $\mathrm{N}$ losses may justify their adoption (Miguez and Bollero, 2005). However, the duration required to realize yield benefits associated with CA practices, is often more than 3 years, and short term yield losses resulting from CA practices may represent a major barrier to adoption in many cropping systems (Pittelkow et al., 2015b). Short-term reductions in risk associated with crop yield loss under extreme weather conditions may be a particularly important factor for grower adoption of CA practices in some cropping systems (e.g. Abdul-Baki and Teasdale, 2007; Brainard et al., 2012; Overstreet et al., 2008), and this factor is likely to increase in importance as the incidence of extreme weather events increases (Rosenzweig and Tubiello, 2007). Future studies quantifying longer-term economic and environmental tradeoffs associated with pest and non-pest regulating services are important for developing a broader understanding of the impacts

32 | Brainard et al. 
of these practices on agricultural sustainability (Zhang et al. 2007). Nonetheless, such long-term benefits are unlikely to be realized, if short-term improvements in profitability of these practices — such as those evaluated in this study — cannot be clearly demonstrated.

Acknowledgements. This work was supported in part through the USDA-NCR SARE Program (Grant number: LNC11-330). The authors would also like to thank the helpful support and advice of the staff at the South West Michigan Research and Extension Center (SWMREC) including Dr. Ron Goldy, and David Francis.

33 | Brainard et al. 


\section{References}

Abdul-Baki, A.A. and Teasdale, J.R., 1997. Snap bean production in conventional tillage and in no-till hairy vetch mulch. HortScience 32: 1191-1193.

Abate, T. and Ampofo, J.K.O., 1996. Insect pests of beans in Africa: their ecology and management. Annual Review of Entomology, 41: 45-73.

Aguyoh, J.N. and J.B. Masiunas. 2003a. Interference of large crabgrass (Digitaria sanguinalis) with snap beans. Weed Science, 51(2):171-176.

Aguyoh, J.N. and J.B. Masiunas. 2003b. Interference of redroot pigweed (Amaranthus retroflexus) with snap beans. Weed Science, 51(2): 202-207.

Archer, D.W. and D.C. Reicosky. 2009. Economic performance of alternative tillage systems in the Northern Corn Belt. Agronomy Journal 101: 296-304.

Banks, P. A. and E. L. Robinson. 1986. Soil reception and activity of acetochlor, alachlor, and metolachlor as affected by wheat (Triticum aestivum) straw and irrigation. Weed Sci. 34:607611.

Bird, G., M. Hausbeck, L.J. Jess, W. Kirk, Z. Szendrei and F. Warner. 2014. Insect, Disease and Nematode Control for Commercial Vegetables. Michigan State University Extension Bulletin E312. East Lansing, MI. Pp. 166.

Bottenberg, H., J. Massiunas, and C. Eastman. 1999. Strip tillage reduces yield loss of snapbean planted in rye mulch. Horttechnology 9:235-240.

Bottenberg, H., J. Masiunas, C. Eastman and D.M. Eastburn. 1997. The impact of rye cover crops on weeds, insects, and diseases in snap bean cropping systems. Journal of sustainable 
agriculture 9:131-155.

Brainard, D. C. and D. C. Noyes. 2012. Strip-tillage and compost influence carrot quality, yield and net returns. Hortscience 47:1073-1079.

Brainard, D. C., B. Henshaw, and S. Snapp. 2012. Hairy vetch varieties and bi-cultures influence cover crop services in strip-tilled sweet corn. Agron J. 104:629-638.

Bryant, A., D. C. Brainard, and Z. Szendrei. 2012. Cover crop mulch and strip tillage influence biological control in cabbage (Brassica oleracea). Abstract 0650 in Entomology 2010: ESA 60th Annual Meeting, Knoxville. TN. Lanham, MD: Entomological Society of America.

Bryant, A.B., Brainard, D.C., Haramoto, E.R., Szendrei, Z. (2013) Cover crop mulch and weed management influences arthropod communities in strip-tilled cabbage. Environmental Entomology 42(2): 293-306.

Cleveland, C.J., Betke, M., Federico, P., Frank, J.D., Hallam, T.G., Horn, J., López, J.D., McCracken, G.F., Medellín, R.A., Moreno-Valdez, A. and Sansone, C.G., 2006. Economic value of the pest control service provided by Brazilian free-tailed bats in south-central Texas. Frontiers in Ecology and the Environment 4: 238-243.

Colloff, M.J., E.A. Lindsay and D.C. Cook. 2013. Natural pest control in citrus as an ecosystem service: Integrating ecology, economics and management at the farm scale. Biological Control 67: 170-177.

Conley, S.P. and Bradley, K.W., 2005. Wheat (Triticum aestivum) Yield Response to Henbit (Lamium amplexicaule) Interference and Simulated Winterkill 1. Weed Technology 19: 902906.

Czapar, G.F., Curry, M.P. and Wax, L.M., 1997. Grower acceptance of economic thresholds for 35 | Brainard et al. 
weed management in Illinois. Weed Technology 11:828-831.

Delahaut, K. 2005. Potato leafhopper. University of Wisconsin Extension. Garden Facts XHT1132.

Dou, Z., R. Fox, \& J.D. Toth. 1995. Seasonal soil nitrate dynamics in corn as affected by tillage and nitrogen source. Soil Science Society of America Journal 59: 858-864.

Farooq, M. and Siddique, K.H., 2015. Conservation Agriculture: Concepts, Brief History, and Impacts on Agricultural Systems. In Conservation Agriculture (pp. 3-17). Springer International Publishing.

FAO. 2014. FAOSTAT. Food and Agriculture Organization of the United Nations. Statistics Division. http://faostat3.fao.org/download/Q/QC/E (accessed 6/21/16).

Gianessi, L.P. and Reigner, N.P., 2007. The value of herbicides in US crop production. Weed Technology 21: 559-566.

Giller, K.E., E. Witter, M. Corbeels and P. Tittonell. 2009. Conservation agricuilture and smallholder farming in Africa: The heretics' view. Field Crops Research 114: 23-34.

Givens, W. A., D. R. Shaw, G. R. Kruger, W. G. Johnson, S. C. Weller, B. G.Young, R. G. Wilson, M.D.K. Owen, and D. Jordan. 2009. Survey of tillage trends following the adoption of glyphosate-resistant crops. Weed Technol. 23:150-155.

Gonzalez, A.L. and Wyman, J.A., 1991. Effect of varying potato leafhopper (Homoptera: Cicadellidae) population densities on snap bean yield. Journal of Economic Entomology 84: 644-649.

Hammond, C.M., Luschei, E.C., Boerboom, C.M. and Nowak, P.J., 2006. Adoption of Integrated 36 | Brainard et al. 
Pest Management Tactics by Wisconsin Farmers 1. Weed Technology 20: 756-767.

Haramoto, E.R. 2014. Weed population dynamics, profitability and nitrogen loss in strip-tilled sweet corn and cabbage. PhD dissertation. Michigan State University. Pp. 241.

Haramoto, E. R. and D. C. Brainard. 2011. Weed emergence and growth in strip-tilled systems: Separating the effects of tillage, cover crops, and crop competition. Abstract 88 in Proceedings of the Weed Science Society of America Annual Meeting, Portland, OR. Champaign, IL: WSSA.

Haramoto, E. R. and D. C. Brainard. 2012. Strip tillage and oat cover crops affect soil moisture and $\mathrm{N}$ mineralization patterns in cabbage. Hortscience 47: 1596-1602.

Haramoto, E.R. and Brainard, D.C., 2016. Spatial and temporal variability in Powell amaranth emergence under strip-tillage with cover crop residue. Weed Science (in press).

Harrison, S.K. 1990. Interference and seed production by common lambsquarters (Chenopodium album) in soybeans (Glycine max). Weed Science 38: 113-118.

Hayden, Z.D., D.C. Brainard, B. Henshaw, and M. Ngouajio. 2012. Winter annual weed suppression in rye-vetch cover crop mixtures. Weed Technology 26: 818-825.

Hobbs, P.R. 2007. Conservation agriculture: what is it and why is it important for future sustainable food production? J. Agric. Sci. 145: 127-137.

Hoyt, G. D. 1999. Tillage and cover residue effects on vegetable yields. Horttechnology 9:351358.

Hoyt, G. D., A. R. Bonnano, and G. C. Parker. 1996. Influence of herbicides and tillage on weed control, yield and quality of cabbage (Brassica oleracea L. Var. capitata). Weed Technol. 10:50-54.

37 | Brainard et al. 
Hoyt, G. D., D. W. Monks, and T. J. Monaco. 1994. Conservation tillage for vegetable production. Horttech. 4:129-135.

Hutchison, W.D., Flood, B. and Wyman, J.A., 2004. Advances in United States sweet corn and snap bean insect pest management. In Insect pest management (pp. 247-278). Springer Berlin Heidelberg.

Johnson, A. M., \& G.D. Hoyt. 1999. Changes to the soil environment under conservation tillage. HortTechnology 9: 380-393.

Jordan, N. and C. Vatovec. 2004. Agroecological benefits from weeds. Pages 137-158 in Inderjit, ed. Weed Biology and Management. Boston: Kluwer.

Kessavalou, A., and D.T. Walters. 1999. Winter rye cover crop following soybean under conservation tillage: Residual soil nitrate. Agron. J. 91:643-649.

Khattat, A.R. and Stewart, R.K., 1975. Damage by tarnished plant bug to flowers and setting pods of green beans. Journal of Economic Entomology 68: 633-635.

Kumar, V., Bellinder, R.R., Gupta, R.K., Malik, R.K. and Brainard, D.C., 2008. Role of herbicide-resistant rice in promoting resource conservation technologies in rice-wheat cropping systems of India: a review. Crop Protection 27: 290-301.

Kumar, V., Singh, S., Chhokar, R.S., Malik, R.K., Brainard, D.C. and Ladha, J.K., 2013. Weed management strategies to reduce herbicide use in zero-till rice-wheat cropping systems of the Indo-Gangetic Plains. Weed Tech. 27: 241-254.

Landis, D. A., S.D. Wratten, and G.M. Gurr. 2000. Habitat management to conserve natural enemies of arthropod pests in agriculture. Annual Review of Entomology 45: 175-201.

Leavitt, M. J., C. C. Sheaffer, and D. L. Wyse. 2011. Rolled winter rye and hairy vetch cover

38 | Brainard et al. 
crops lower weed density but reduce vegetable yields in no-tillage organic production. Hortsci. 46:387-395.

Letourneau, D.K. 1990. Mechanisms of predator accumulation in a mixed crop system. Ecol. Entomol. 15: 63-69.

Locke, M. A. and C. T. Bryson. 1997. Herbicide-soil interactions in reduced tillage and plant residue management systems. Weed Sci. 45:307-320.

Lonsbary, S. K., J. O’Sullivan, and C. J. Swanton. 2004. Reduced tillage alternatives for machine- harvested cucumbers. Hortscience 39:991-995.

Lugo, M. and R. E. Talbert. 1989. Large crabgrass and smooth pigweed interference in snap bean. Proc. Annu. Meet. Ark. Hortic. Soc. 110:132.

Luna, J. M. and M. L. Staben. 2002. Strip tillage for sweet corn production: yield and economic return. Hortscience 37:1040-1044.

Luna, J. M., J. P. Mitchell, and A. Shrestha. 2012. Conservation tillage in organic agriculture: evolution toward hybrid systems in the Western USA. Renew. Agric. Food Syst. 27:21-30.

Miguez, F.E. and Bollero, G.A., 2005. Review of corn yield response under winter cover cropping systems using meta-analytic methods. Crop Science 45: 2318-2329.

Mochizuki, M. J., A. Rangarajan, R. R. Bellinder, T. N. Bjo r̈kman, and H. M. Van Es. 2007. Overcoming compaction limitations on cabbage growth and yield in the transition to conservation tillage. Hortscience 42:1690-1694.

Mochizuki, M. J., A. Rangarajan, R. R. Bellinder, T. Bjo rkman, and H. M. Van Es. 2008. Rye mulch management affects short-term indicators of soil quality in the transition to conservation tillage for cabbage. Hortscience 43:862-867.

39 | B rainard et al. 
Naseri, B. and Mousavi, S.S., 2015. Root rot pathogens in field soil, roots and seeds in relation to common bean (Phaseolus vulgaris), disease and seed production. International Journal of Pest Management, 61: 60-67.

Neill, S.P. and D.R. Lee. 2001. Explaining the Adoption and Disadoption of Sustainable Agriculture: The Case of Cover Crops in Northern Honduras. Economic Development and Cultural Change 49: 793-820.

NeSmith, D. S., G. Hoogenboom, and D. V. McCraken. 1994. Summer squash production using conservation tillage. Hortscience 29:28-30.

Norris, R. F. and M. Kogan. 2005. Ecology of interactions between weeds and arthropods. Annu. Rev. Entomol. 50:479-503.

Ogg, A. G., R. H. Stephens, and D. R. Gealy. 1993. Growth analysis of mayweed cohamomile (Anthemis cotula) interference in peas (Pisum sativum). Weed Sci. 41:394-402.

Overstreet, L. F. and G. D. Hoyt. 2008. Effects of strip-tillage and production inputs on soil biology across a spatial gradient. Soil Sci. Soc. Am. J. 72:1454-1463.

Overstreet, L. F., G. D. Hoyt, and J. Imbriani. 2010. Comparing nematode and earthworm communities under combinations of conventional and conservation vegetable production practices. Soil Tillage Res. 110:42-50.

Page, K., Y. Dang, and R. Dalal. 2013. Impacts of conservation tillage on soil quality, including soil-borne crop diseases, with a focus on semi-arid grain cropping systems. Australasian J. of Plant Pathology 42:363-377

Palm, C., H. Blanco-Canqui, F. DeClerck, L. Gatere and P. Grace. 2014. Conservation

40 | Brainard et al. 
agriculture and ecosystem services: An overview. Agriculture, Ecosystems and Environment 187: 87-105.

Pittelkow, C.M., Liang, X., Linquist, B.A., Van Groenigen, K.J., Lee, J., Lundy, M.E., van Gestel, N., Six, J., Venterea, R.T. and van Kessel, C., 2015a. Productivity limits and potentials of the principles of conservation agriculture. Nature 517: 365-368.

Pittelkow, C.M., Linquist, B.A., Lundy, M.E., Liang, X., Van Groenigen, K.J., Lee, J., Van Gestel, N., Six, J., Venterea, R.T. and Van Kessel, C., 2015b. When does no-till yield more? A global meta-analysis. Field Crops Research 183: 156-168.

Reicosky, D.C., and M.J. Lindstrom. 1993. Fall tillage method: Effect on short-term carbon dioxide flux from soil. Agronomy Journal 85:1237-1243.

Reicosky, D.C., 2015. Conservation tillage is not conservation agriculture. Journal of Soil and Water Conservation 70: 103A-108A.

Ristaino, J.B. G. Parra and C.L. Campbell. 1997. Suppression of Phytophthora blight in bell pepper by a no-till wheat cover crop. Phytopathology 87:242-249.

Rosenzweig, C. and Tubiello, F.N., 2007. Adaptation and mitigation strategies in agriculture: an analysis of potential synergies. Mitigation and Adaptation Strategies for Global Change 12: 855-873.

SAS v9.3 2014. SAS Institute, Cary, NC.

Schellhorn, N.A. and V.L. Sork. 1997. The impact of weed diversity on insect population dynamics and crop yield in collards, Brassica oleraceae (Brassicaeae). Oecologia 111:233240.

Schroder, J. J., W. Van Dijk, and W.J.M. De Groot. 1996. Effects of cover crops on the nitrogen

41 | B rainard et al. 
fluxes in a silage maize production system. NJAS Wageningen journal of life sciences, 44: 293-315.

Shearin, A. F., Reberg-Horton, S. and Gallandt, E. 2007. Direct effects of tillage on the activity density of ground beetle (Coleoptera: Carabidae) weed seed predators. Environ. Entomol. 36:1140-1146.

Snapp, S., S. M. Swinton, R. Labarta, D. Mutch, J. R. Black, R. Leep, J. Nyiraneza, and K. O’Neil. 2005. Evaluating cover crops for benefits, costs and performance within cropping system niches. Agron. J. 97:322-332.

Stein, D. 2011. 2011 Custom machine and work rate estimates. Michigan State University Extension, East Lansing, MI.

Stewart, R.K. and Khattat, A.R., 1980. Pest status and economic thresholds of the tarnished plant bug, Lygus lineolaris (Hemiptera (Heteroptera): Miridae), on green beans in Quebec. The Canadian Entomologist, 112: 301-305.

Tarkalson, D. D., D. L. Bjorneberg, and A. Moore. 2012. Effects of tillage system and nitrogen supply on sugarbeet production. J. Sugar Beet Res. 49:79-102.

Teasdale, J. R. 1998. Cover crops, smother plants, and weed management. Pages 247-270 in J. L. Hatfield, D. D. Buhler, and B. A. Stewart, eds. Integrated Weed and Soil Management. Chelsea, MI: Ann Arbor.

Teasdale, J. R. and C. L. Mohler. 2000. The quantitative relationship between weed emergence and the physical properties of mulches. Weed Science 48:385-392.

Toews, M.D., R.S. Tubbs, D.Q. Wann and D. Sullivan. 2010. Thrips (Thysanoptera:Thripidae) mitigation in seedling cotton using strip tillage and winter cover crops. Pest Management 
Science 66: 1089-1095.

Wagger, M.G. 1989. Time of desiccation effects on plant composition and subsequent nitrogen release from several winter annual cover crops. Agronomy Journal 81:236-241.

Wallace, R. W. and R. R. Bellinder. 1989. Potato (Solanum tuberosum) yields and weed populations in conventional and reduced tillage systems. Weed Technology. 3:590-595.

Walters, S. A. and J. D. Kindhart. 2002. Reduced tillage practices for summer squash production in southern Illinois. HortTechnology. 12:11-14.

Wang, G. and M. Ngouajio. 2008. Integration of cover crop, conservation tillage, and low herbicide rate for machine-harvested pickling cucumbers. HortScience 43:1770-1774.

Warncke, D., J. Dahl, and B. Zandstra. 2004. Nutrient recommendations for Michigan vegetable crops. Michigan State University Extension Bulletin Publication E2934. East Lansing, MI.

Wilkinson, T.K. and D.A. Landis 2005. Habitat diversification in biological control: the role of plant resources, pp. 305-325. In F.L. Wackers, P.C.J. van Rijn, and J. Bruin (eds.), Plantprovided food for carnivorous insects. Cambridge University Press, Cambridge, U.K.

Wisler, G. C. and R. F. Norris. 2005. Interactions between weeds and cultivated plants as related to management of plant pathogens. Weed Science 53:914-917.

Wyland, L.J., Jackson, L.E., Chaney, W.E., Klonsky, K., Koike, S.T. and Kimple, B., 1996. Winter cover crops in a vegetable cropping system: Impacts on nitrate leaching, soil water, crop yield, pests and management costs. Agriculture, Ecosystems \& Environment, 59: 1-17. 
Zandstra, B.H. 2011. Weed Control Guide for Vegetable Crops. Michigan State University Extension Bulletin E-433. East Lansing, MI.

Zhang, W., Ricketts, T.H., Kremen, C., Carney, K. and Swinton, S.M., 2007. Ecosystem services and dis-services to agriculture. Ecological Economics 64: 253-260.

44 | Brainard et al. 
Table 1. Schedule of major field operations and data collection events, 2009/10 and 2010/11.

\begin{tabular}{lcc} 
& \multicolumn{2}{c}{ Date } \\
\cline { 2 - 3 } Event & 2009/10 & 2010/11 \\
\hline Rye planted & 2-Sep & 10-Sep \\
Winter annual weed density evaluated & 29-Apr & 10-May \\
Rye and weed biomass sampling & 14-May & 10-May \\
Glyphosate application & 17-May & 16-May \\
Flail mowing of rye & 24-May & 23-May \\
Fertilize/Plow/Disk/Harrow/Strip-till & 25-May & 1-Jun \\
Snap bean planting & 26-May & 2-Jun \\
S-metolachlor application & 27-May & 3-Jun \\
Weed emergence evaluation & 21-Jun & 16-Jun \\
Bentazon application & 24-Jun & 29-Jun \\
Clethodim application & 30-Jun & 7-Jul \\
Insect evaluation & 1-Jul to 16 Jul & 16-Jun to 26 Jul \\
Final weed density evaluated & 19-Jul & 26-Jul \\
Snap bean harvest & 19-Jul & 26-Jul \\
\hline
\end{tabular}

${ }^{a}$ High weed management treatment only 
Table 2. Winter annual weed density, April 2010 and 2011.

\begin{tabular}{|c|c|c|c|c|c|c|c|c|c|c|}
\hline & \multicolumn{2}{|c|}{ LAMAM $^{\mathrm{a}}$} & \multicolumn{2}{|c|}{ LAMPU $^{a}$} & \multicolumn{2}{|c|}{ STEME $^{a}$} & \multicolumn{2}{|c|}{ SCRAN $^{a}$} & \multicolumn{2}{|c|}{ ARBTH $^{a}$} \\
\hline & 2010 & 2011 & 2010 & 2011 & 2010 & 2011 & 2010 & 2011 & 2010 & 2011 \\
\hline & & & & & --plan & $\mathrm{s} \mathrm{m}^{-2}$ & & & & \\
\hline \multicolumn{11}{|c|}{ Cover Crop } \\
\hline None & $40 a$ & $24 a$ & $13 \mathrm{a}$ & 0 & 41 & 5 & 3 & 391 & $326 a$ & $16 a$ \\
\hline Rye & $9 \mathrm{~b}$ & $2 b$ & $4 \mathrm{~b}$ & 0 & 40 & 15 & 2 & 260 & $127 \mathrm{~b}$ & $4 \mathrm{~b}$ \\
\hline
\end{tabular}

Statistical significance $(p=0.05)$ is indicated by different letters within the same column.

a $\mathrm{LAMAM}=$ Henbit $;$ LAMPU $=$ Purple deadnettle $;$ STEME = common chickweed; SCRAN

$=$ knawal $;$ ARBTH $=$ mouse-ear thale. 
Table 3. Mean emergence of weeds, 2010 and 2011.

\begin{tabular}{|c|c|c|c|c|c|c|}
\hline \multirow[b]{2}{*}{ Tillage } & \multicolumn{2}{|c|}{$\mathrm{CHEAL}^{\mathrm{ab}}$} & \multicolumn{2}{|c|}{ AMAPO $^{\mathrm{ab}}$} & \multicolumn{2}{|c|}{ DIGSA $^{\text {ac }}$} \\
\hline & 2010 & 2011 & 2010 & 2011 & 2010 & 2011 \\
\hline & \multicolumn{6}{|c|}{ 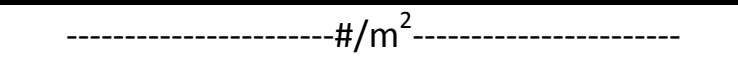 } \\
\hline \multicolumn{7}{|l|}{ Full-width } \\
\hline No-rye & 72 a & $35 a b$ & 47 & 69 & 17 & $0 \mathrm{~d}$ \\
\hline Rye & 63 a & $57 a b$ & 25 & 69 & 52 & $12 \mathrm{bc}$ \\
\hline \multicolumn{7}{|l|}{ Strip-tillage } \\
\hline No-rye & 70 a & 65 a & 15 & 85 & 200 & $26 a$ \\
\hline Rye & $14 \mathrm{~b}$ & $28 \mathrm{~b}$ & 4 & 55 & 14 & $11 \mathrm{c}$ \\
\hline \multicolumn{7}{|l|}{ ANOVA } \\
\hline Tillage (T) & NS & NS & NS & NS & NS & 0.0007 \\
\hline Cover (C) & 0.003 & NS & NS & NS & NS & NS \\
\hline$T \times C$ & 0.011 & 0.044 & NS & NS & NS & 0.0125 \\
\hline
\end{tabular}

Statistical significance $(p=0.05)$ is indicated by different

letters within the same column.

${ }^{a} \mathrm{CHEAL}=$ common lambsquaters; $\mathrm{AMAPO}=$ Powell amaranth; DIGSA = large crabgrass

${ }^{\mathrm{b}}$ Weed seeds were sown at planting

${ }^{\mathrm{c}}$ Ambient weed population 
Table 4. Mean density of summer annual weeds overtopping the bean canopy at harvest, 2010-2011.

\begin{tabular}{|c|c|c|c|c|c|c|c|c|c|c|c|c|c|c|c|c|}
\hline & \multicolumn{4}{|c|}{ Common lambsquarters } & \multicolumn{4}{|c|}{ Powell amaranth } & \multicolumn{4}{|c|}{ Large crabgrass } & \multicolumn{4}{|c|}{ TOTAL } \\
\hline & \multicolumn{2}{|c|}{ Between-row } & \multicolumn{2}{|c|}{ In-row } & \multicolumn{2}{|c|}{ Between-row } & \multicolumn{2}{|c|}{ In-row } & \multicolumn{2}{|c|}{ Between-row } & \multicolumn{2}{|c|}{ In-row } & \multicolumn{2}{|c|}{ Between-row } & \multicolumn{2}{|c|}{ In-row } \\
\hline & 2010 & 2011 & 2010 & 2011 & 2010 & 2011 & 2010 & 2011 & 2010 & 2011 & 2010 & 2011 & 2010 & 2011 & 2010 & 2011 \\
\hline \multicolumn{17}{|l|}{ Tillage main effect } \\
\hline Full-width tillage & 0.64 & 1.03 & 2.02 & 0.45 & 0.08 & 0.08 & 0.66 & 0.33 & 0.00 & 0.02 & $1.97 \mathrm{a}$ & $0.78 \mathrm{a}$ & 0.72 & 1.13 & 4.65 & $1.56 \mathrm{a}$ \\
\hline Strip-tillage & 0.64 & 0.26 & 1.97 & 0.45 & 0.19 & 0.14 & 0.81 & 0.25 & 0.32 & 0.04 & $4.54 \mathrm{~b}$ & $3.03 \mathrm{~b}$ & 1.15 & 0.64 & 7.33 & $4.02 \mathrm{~b}$ \\
\hline \multicolumn{17}{|c|}{ Cover crop main effect } \\
\hline No rye & 0.83 & 0.60 & 1.86 & 0.41 & 0.16 & $0.22 \mathrm{a}$ & 0.82 & 0.29 & 0.27 & 0.00 & $2.30 \mathrm{a}$ & 1.68 & 0.69 & 0.44 & 4.98 & 2.38 \\
\hline Rye & 0.46 & 0.69 & 2.13 & 0.49 & 0.11 & $0.02 \mathrm{~b}$ & 0.66 & 0.29 & 0.06 & 0.06 & $4.21 \mathrm{~b}$ & 2.13 & 0.27 & 0.06 & 7.00 & 3.20 \\
\hline \multicolumn{17}{|c|}{ Weed Management main effect } \\
\hline Low & 0.54 & $1.29 \mathrm{a}$ & 2.46 & $0.70 \mathrm{a}$ & 0.13 & $0.22 \mathrm{a}$ & 0.82 & 0.49 & 0.11 & 0.00 & 3.28 & 1.85 & 0.78 & $1.51 \mathrm{a}$ & 6.56 & 3.32 \\
\hline High & 0.75 & $0.00 \mathrm{~b}$ & 1.53 & $0.21 \mathrm{~b}$ & 0.13 & $0.00 \mathrm{~b}$ & 0.66 & 0.08 & 0.21 & 0.06 & 3.23 & 1.97 & 1.10 & $0.26 \mathrm{~b}$ & 5.41 & 2.25 \\
\hline \multicolumn{17}{|l|}{ Tillage $x$ cover } \\
\hline \multicolumn{17}{|l|}{ Full-width tillage } \\
\hline No rye & 0.91 & 0.72 & 2.62 & 0.41 & 0.11 & $0.16 \mathrm{ab}$ & 0.87 & 0.33 & 0.00 & 0.00 & 0.77 & 0.57 & 1.02 & 0.88 & 4.26 & 1.31 \\
\hline Rye & 0.38 & 1.33 & 1.42 & 0.49 & 0.05 & $0.00 \mathrm{~b}$ & 0.44 & 0.33 & 0.00 & 0.04 & 3.17 & 0.98 & 0.43 & 0.04 & 5.03 & 1.80 \\
\hline \multicolumn{17}{|l|}{ Strip-tillage } \\
\hline No rye & 0.75 & 0.48 & 1.09 & 0.41 & 0.21 & $0.28 \mathrm{a}$ & 0.77 & 0.25 & 0.54 & 0.00 & 3.83 & 2.79 & 0.35 & 0.00 & 5.69 & 3.44 \\
\hline Rye & 0.54 & 0.04 & 2.84 & 0.49 & 0.16 & $0.04 \mathrm{~b}$ & 0.87 & 0.25 & 0.11 & 0.08 & 5.25 & 3.28 & 0.11 & 0.08 & 8.97 & 4.59 \\
\hline \multicolumn{17}{|l|}{ ANOVA } \\
\hline Tillage (T) & NS & NS & NS & NS & NS & NS & NS & NS & NS & NS & 0.0458 & 0.0001 & NS & NS & NS & 0.0040 \\
\hline Cover $(\mathrm{C})$ & NS & NS & NS & NS & NS & 0.0340 & NS & NS & NS & NS & 0.0387 & NS & NS & NS & NS & NS \\
\hline Weed Man. (W) & NS & $<0.0001$ & NS & 0.0004 & NS & 0.0030 & NS & NS & NS & NS & NS & NS & NS & 0.0030 & NS & NS \\
\hline $\mathrm{T} \times \mathrm{C}$ & NS & NS & NS & NS & NS & 0.0340 & NS & NS & NS & NS & NS & NS & NS & NS & NS & NS \\
\hline $\mathrm{T} \times \mathrm{W}$ & NS & NS & NS & NS & NS & NS & NS & NS & NS & NS & NS & NS & NS & NS & NS & NS \\
\hline$C \times W$ & NS & NS & NS & NS & NS & NS & NS & NS & NS & NS & NS & NS & NS & 0.0370 & NS & NS \\
\hline $\mathrm{T} \times \mathrm{C} \times \mathrm{W}$ & NS & NS & NS & NS & NS & NS & NS & NS & NS & NS & NS & NS & NS & NS & NS & NS \\
\hline
\end{tabular}

Statistical significance $(p=0.05)$ is indicated by different letters within the same column. 
Table 5. Effects of tillage and rye cover crops on insect pests and natural enemies.

\begin{tabular}{|c|c|c|c|c|c|c|c|c|c|c|c|c|c|c|c|c|c|c|}
\hline \multirow[b]{3}{*}{ Tillage } & \multicolumn{8}{|c|}{ Insect pests } & \multicolumn{10}{|c|}{ Natural enemies } \\
\hline & \multicolumn{2}{|c|}{$\mathrm{PLH}^{\mathrm{a}}$} & \multicolumn{2}{|c|}{$\mathrm{TPB}^{\mathrm{b}}$} & \multicolumn{2}{|c|}{ Aphid } & \multicolumn{2}{|c|}{ Thrip } & \multicolumn{2}{|c|}{ Striped thrips } & \multicolumn{2}{|c|}{ Ladybeetles } & \multicolumn{2}{|c|}{ Spiders } & \multicolumn{2}{|c|}{ Pentatomids } & \multicolumn{2}{|c|}{ Parasitoids } \\
\hline & 2010 & 2011 & 2010 & 2011 & 2010 & 2011 & 2010 & 2011 & 2010 & 2011 & 2010 & 2011 & 2010 & 2011 & 2010 & 2011 & 2010 & 2011 \\
\hline \multicolumn{19}{|c|}{ Cover Crop Main Effect } \\
\hline None & 0.00 & 8.74 & $0.77 \mathrm{a}$ & 0.70 & $1.87 \mathrm{a}$ & 2.32 & 3.67 & 7.31 & 3.38 & 0.70 & 1.45 & $0.05 \mathrm{a}$ & 0.51 & $0.20 \mathrm{a}$ & 0.06 & 0.02 & 1.54 & 0.21 \\
\hline Rye & 0.00 & 8.36 & $3.17 \mathrm{~b}$ & 0.59 & $4.60 \mathrm{~b}$ & 2.43 & 6.17 & 6.66 & 7.05 & 0.71 & 0.33 & $0.16 \mathrm{~b}$ & 0.22 & $0.07 \mathrm{~b}$ & 1.39 & 0.02 & 0.72 & 0.13 \\
\hline \multicolumn{19}{|c|}{ Tillage $x$ Cover } \\
\hline \multicolumn{19}{|c|}{ Full-width tillage } \\
\hline None & 0.00 & 11.07 & 1.17 & 0.57 & 2.50 & 1.71 & 2.77 & 7.83 & 4.75 & $0.93 a b$ & $1.00 \mathrm{a}$ & 0.07 & 0.25 & 0.21 & 0.00 & 0.00 & $1.08 \mathrm{ab}$ & $0.21 \mathrm{a}$ \\
\hline Rye & 0.00 & $9.11^{\mathrm{A}}$ & 3.33 & 0.82 & 4.77 & 2.29 & 8.00 & 6.43 & 5.00 & $0.39 \mathrm{~b}$ & $0.67 \mathrm{ab}$ & 0.11 & 0.33 & 0.11 & 0.33 & 0.00 & $1.44 \mathrm{a}$ & $0.00 \mathrm{~b}$ \\
\hline \multicolumn{19}{|c|}{ Strip tillage } \\
\hline None & 0.00 & 6.40 & 0.22 & 0.82 & 1.00 & 2.93 & 4.57 & 6.79 & 2.00 & $0.46 a b$ & $1.90 \mathrm{a}$ & 0.04 & 0.78 & 0.18 & 0.11 & 0.04 & $2.00 \mathrm{a}$ & $0.21 a$ \\
\hline Rye & 0.00 & $7.61^{\mathrm{B}}$ & 3.00 & 0.36 & 4.43 & 2.57 & 4.33 & 6.90 & 9.10 & $1.04 \mathrm{a}$ & $0.00 \mathrm{~b}$ & 0.21 & 0.11 & 0.04 & 2.44 & 0.04 & $0.00 \mathrm{~b}$ & $0.25 \mathrm{a}$ \\
\hline \multicolumn{19}{|l|}{ ANOVA } \\
\hline Tillage $(\mathrm{T})$ & NS & 0.0097 & NS & NS & NS & NS & NS & NS & NS & NS & NS & NS & NS & NS & NS & NS & NS & 0.0300 \\
\hline Cover (C) & NS & NS & 0.0110 & NS & 0.0677 & NS & NS & NS & NS & NS & 0.0229 & 0.0293 & NS & 0.0107 & NS & NS & NS & NS \\
\hline $\mathrm{T} \times \mathrm{C}$ & NS & 0.0793 & NS & NS & NS & NS & NS & NS & NS & 0.0375 & 0.0283 & NS & NS & NS & NS & NS & 0.0131 & 0.0315 \\
\hline
\end{tabular}

Statistical significance $(p=0.05)$ is indicated by different letters within the same column.

${ }^{\text {a }}$ Potato leafhopper (nymphs and adults)

${ }^{\mathrm{b}}$ Tarnished plant bug (nymphs and adults)

'Plants were sampled 3 times in 2010, and 7 times in 2011. Analysis was conducted on mean number per sampling date. See figures 2 and 3 for more detail on PLF and TPB. 
Table 6. Mean (+-se) bean yield and harvest index, 2010 and 2011.

\begin{tabular}{|c|c|c|c|c|}
\hline \multirow[b]{2}{*}{ Tillage } & \multicolumn{2}{|c|}{ Yield } & \multicolumn{2}{|c|}{ Harvest index } \\
\hline & 2010 & 2011 & 2010 & 2011 \\
\hline & \multicolumn{2}{|c|}{---------T/ha--------- } & \multicolumn{2}{|c|}{--------\%-------- } \\
\hline \multicolumn{5}{|l|}{ Tillage (T) } \\
\hline Full width tillage & 5.04 & 5.29 & 43.5 & 33.3 \\
\hline Strip tillage & 4.98 & 5.02 & 41.8 & 33.4 \\
\hline \multicolumn{5}{|l|}{ Cover crop (C) } \\
\hline No rye & 5.09 & 5.31 & 42.9 & 34.1 \\
\hline Rye & 4.94 & 5.01 & 42.5 & 32.7 \\
\hline \multicolumn{5}{|c|}{ Weed management (W) } \\
\hline Low & 5.14 & 5.24 & 43.2 & 34.1 \\
\hline High & 4.89 & 5.07 & 42.1 & 32.6 \\
\hline \multicolumn{5}{|l|}{ ANOVA } \\
\hline Tillage $(T)$ & NS & NS & NS & NS \\
\hline Cover crop (C) & NS & NS & NS & NS \\
\hline Weed man (W) & NS & NS & NS & NS \\
\hline $\mathrm{T} \times \mathrm{C}$ & NS & NS & NS & NS \\
\hline$T \times W$ & NS & NS & NS & NS \\
\hline$C \times W$ & NS & NS & NS & NS \\
\hline$T \times C \times W$ & NS & NS & NS & NS \\
\hline
\end{tabular}


Table 7. Estimated changes in costs of pest management, tillage and cover cropping in FWT-R, ST-NR and ST-R c ompared to FWTNR.

\begin{tabular}{|c|c|c|c|}
\hline & \multicolumn{3}{|c|}{$\begin{array}{c}\text { Estimated costs }(+) \text { or } \\
\text { savings }(-)\end{array}$} \\
\hline & FWT-R & ST-NR & ST-R \\
\hline & \multicolumn{3}{|c|}{------\$ ha ${ }^{-1}--------$} \\
\hline \multicolumn{4}{|l|}{ Pest management costs ${ }^{a}$} \\
\hline \multicolumn{4}{|l|}{ Weeds } \\
\hline Winter annuals & 0.0 & 29.9 & 0.0 \\
\hline Large crabgrass & 14.1 & 14.1 & 14.1 \\
\hline Powell amaranth & 0.0 & 0.0 & 0.0 \\
\hline Common lambsquarters & 0.0 & 0.0 & 0.0 \\
\hline \multicolumn{4}{|l|}{ Insects } \\
\hline Potato leaf hopper & 0.0 & -18.6 & -18.6 \\
\hline Tarnished plant bug & 18.6 & 0.0 & 18.6 \\
\hline TOTAL Weed & 14.1 & 44.0 & 14.1 \\
\hline TOTAL Insect & 18.6 & -18.6 & 0.0 \\
\hline TOTAL PEST (Weeds+Insects) & 32.7 & 25.3 & 14.1 \\
\hline \multicolumn{4}{|l|}{ Cover crop management costs } \\
\hline Rye seed ${ }^{b}$ & 88.7 & 0.0 & 88.7 \\
\hline Rye planting (drill) ${ }^{c}$ & 25.3 & 0.0 & 25.3 \\
\hline Glyphosate product $^{d}$ & 44.9 & 0.0 & 44.9 \\
\hline Glyphosate application ${ }^{c}$ & 13.5 & 0.0 & 13.5 \\
\hline Rye mowing ${ }^{c}$ & 0.0 & 0.0 & 29.2 \\
\hline Total Rye Management & 172.4 & 0.0 & 201.6 \\
\hline \multicolumn{4}{|l|}{ Tillage costs } \\
\hline Strip till ${ }^{b}$ & 0.0 & 38.2 & 38.2 \\
\hline Moldboard plow ${ }^{\text {b }}$ & 0.0 & -42.9 & -42.9 \\
\hline Disk ${ }^{\text {be }}$ & 27.0 & -27.0 & -27.0 \\
\hline Harrow $^{b}$ & 0.0 & -19.5 & -19.5 \\
\hline Total tillage & 27.0 & -51.2 & -51.2 \\
\hline GRAND TOTAL & 232.1 & -25.8 & 164.5 \\
\hline
\end{tabular}

Abbreviations: FWT=Full width tillage; $R=$ Rye cover crop; NR=No rye cover crop; ST=Strip tillage

${ }^{a}$ See Tables A.1 and A.2 for underlying threshold and cost assumptions.

${ }^{\mathrm{b}}$ Assumes rye sown at $125 \mathrm{~kg} \mathrm{ha}^{-1}$ and rye seed cost of $\$ 0.71 \mathrm{~kg}^{-}$ ${ }^{1}$; assumes no additional tillage required in the fall to sow rye since growers typically disk for weed and disease management even when rye is not being planted.

${ }^{c}$ Estimates from Stein et al. (2011). 
Table A1. Pest management threshold, rate and cost assumptions

Pesticide product, rate and cost assumptions when thresholds are exceeded

\begin{tabular}{|c|c|c|c|c|c|c|c|c|}
\hline \multirow[b]{3}{*}{ Pest } & & & \multicolumn{6}{|c|}{ are exceeded } \\
\hline & \multicolumn{2}{|c|}{ Threshold Assumptions and Sources ${ }^{a}$} & \multirow[b]{2}{*}{ Product } & \multirow{2}{*}{ 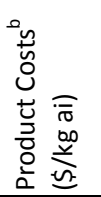 } & \multirow{2}{*}{ 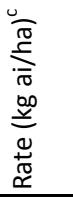 } & \multirow{2}{*}{ 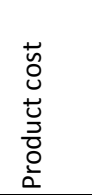 } & \multirow{2}{*}{ 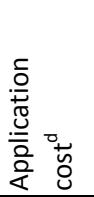 } & \multirow{2}{*}{$\begin{array}{l}\stackrel{\bigsqcup}{0} \\
\frac{0}{\pi} \\
\stackrel{0}{0} \\
\vdash\end{array}$} \\
\hline & Action threshold & Source(s) & & & & & & \\
\hline & & & & & & \multicolumn{3}{|c|}{----------\$/ha---------- } \\
\hline Crabgrass & 8 plants $\mathrm{m}^{-2}$ & Aguyoh and Masiunas, 2003a & Clethodim & 192.75 & 0.08 & 14.68 & 13.46 & 28.14 \\
\hline Common lambsquarters & 3 plants $\mathrm{m}^{-2}$ & $\begin{array}{l}\text { Aguyoh and Masiunas, } \\
\text { 2003b; Harrison, } 1990\end{array}$ & Bentazon & 48.26 & 0.98 & 47.30 & 13.46 & 60.76 \\
\hline Powell amaranth & 3 plants $\mathrm{m}^{-2}$ & Aguyoh and Masiunas, 2003b & Fomesafen & 120.14 & 0.28 & 33.64 & 13.46 & 47.10 \\
\hline Winter annual weeds & $100 \mathrm{~g} \mathrm{~m}^{-2}$ & $\begin{array}{l}\text { Ogg et al., 1993; Conley and } \\
\text { Bradley, } 2005\end{array}$ & Glyphosate & 13.36 & 2.24 & 29.94 & 0 & 29.94 \\
\hline Potato leaf hopper & 1 nymph/plant & $\begin{array}{l}\text { Delahaut, 2005; Cook et al. } \\
\text { 2004; Bird et al. } 2014\end{array}$ & $\begin{array}{l}\text { lambda- } \\
\text { cyhalothrin }\end{array}$ & 14.91 & 1.60 & 23.80 & 13.46 & 37.26 \\
\hline Tarnished plant bug & 0.2 adults/plant & $\begin{array}{l}\text { Bird et al., 2014; Stewart and } \\
\text { Khattat, 1980; Khattat and } \\
\text { Stewart, } 1975\end{array}$ & $\begin{array}{l}\text { lambda- } \\
\text { cyhalothrin }\end{array}$ & 14.91 & 1.60 & 23.80 & 13.46 & 37.26 \\
\hline
\end{tabular}

${ }^{\mathrm{a}}$ Threshold assumptions were based on sources listed in combination with our personal observations of snap bean management in MI (see text for details). For summer annual weeds, threshold values were converted from $\mathrm{m}$-row to $\mathrm{m}^{-2}$ by multiplying by 4 (assumes 0.25 in-row zone).

${ }^{\mathrm{b}}$ Product costs are from local MI pesticide dealer (Crop Protection Services, 2012) and represent typical prices paid by MI snap bean growers.

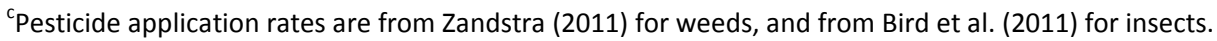

${ }^{d}$ From Stein (2011). For glyphosate, it is assumed that no additional application costs would be incurred, because the pesticide could be tank mixed with pre-emergence herbicides (e.g. s-metolachlor) that would be applied regardless of treatment. 
Table A.2. Assumed probabilities of different pest density outcomes relative to threhsolds for strip tillage and cover crop practices ${ }^{\cdot a}$

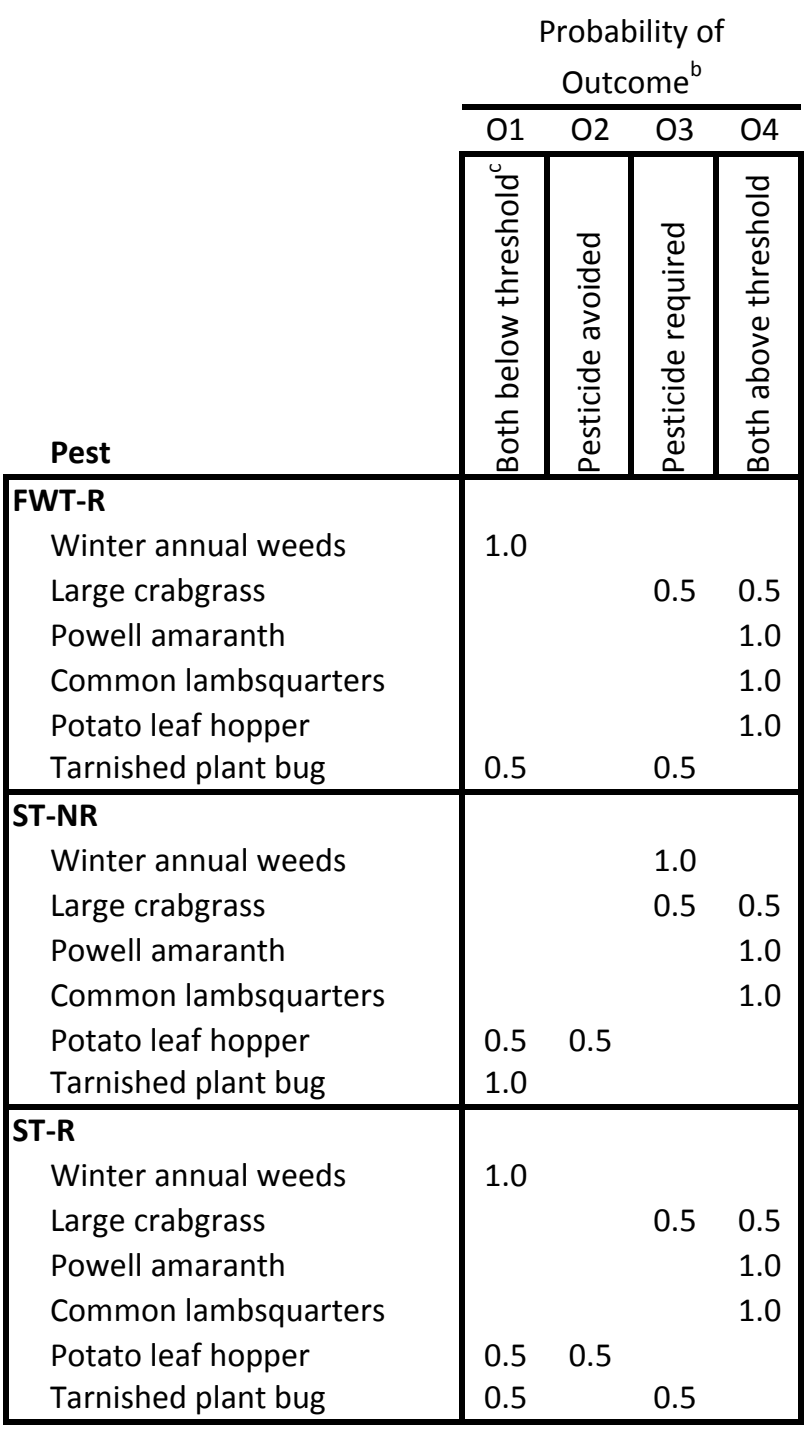

${ }^{\mathrm{a}}$ Abbreviations: $\mathrm{FWT}=$ Full width tillage; $\mathrm{R}=$ Rye cover crop; NR=No rye cover crop; ST=Strip tillage

${ }^{b}$ See text. 01: Pest density in the control treatment (Dc) and the pest density in the alternative treatment (Da) are both less than the threshold density (Dt); O2: $\mathrm{Dc}>\mathrm{Dt}$ and Da < Dt; O3: Dc < Dt and Da > Dt; O4: Dc > Dt and Da $>$ Dt.

' See Table A.1 for threshold assumptions; Pobabilities are based on observed weed (Table 3; Fig. 1) and insect (Table 5; Figs. 2 and 3 ) abundance relative to thresholds. 


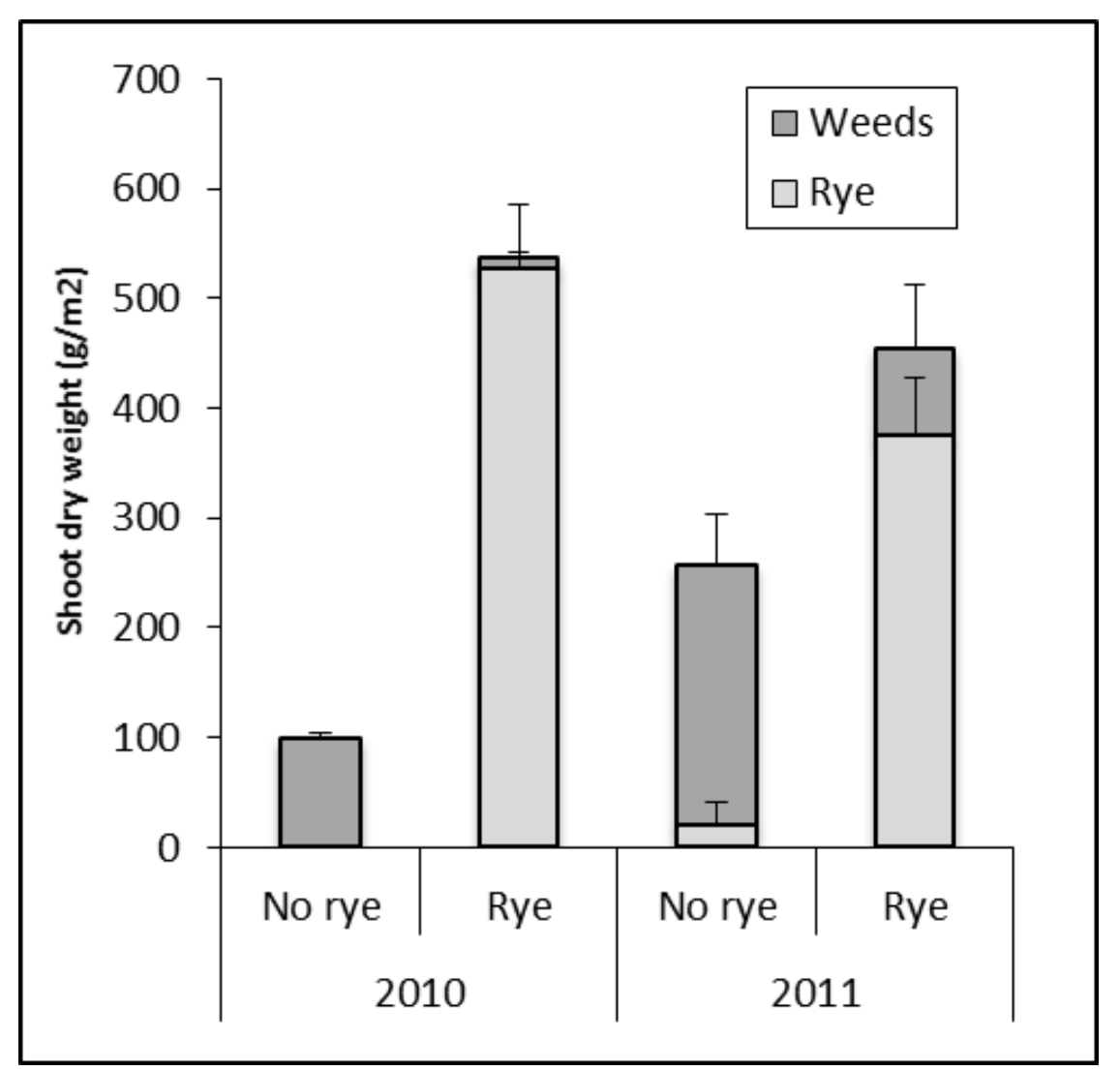

Figure 1. Mean (+se) shoot dry weight of winter rye cover crop and winter annual weeds, 2010 and 2011. 


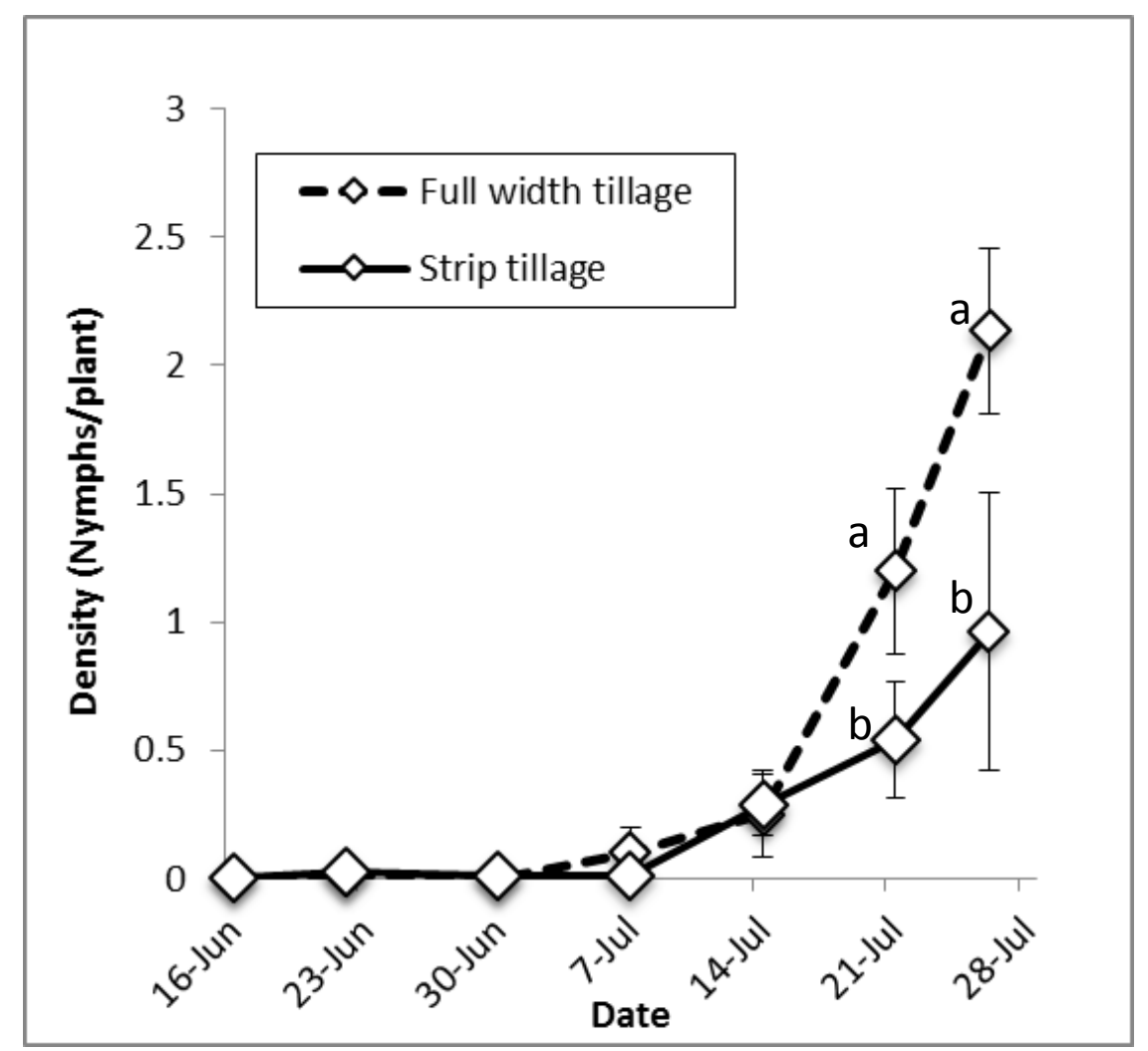

Figure 2. Main effect of tillage on mean ( $\pm s e)$ density of potato leafhopper nymphs, 2011. 


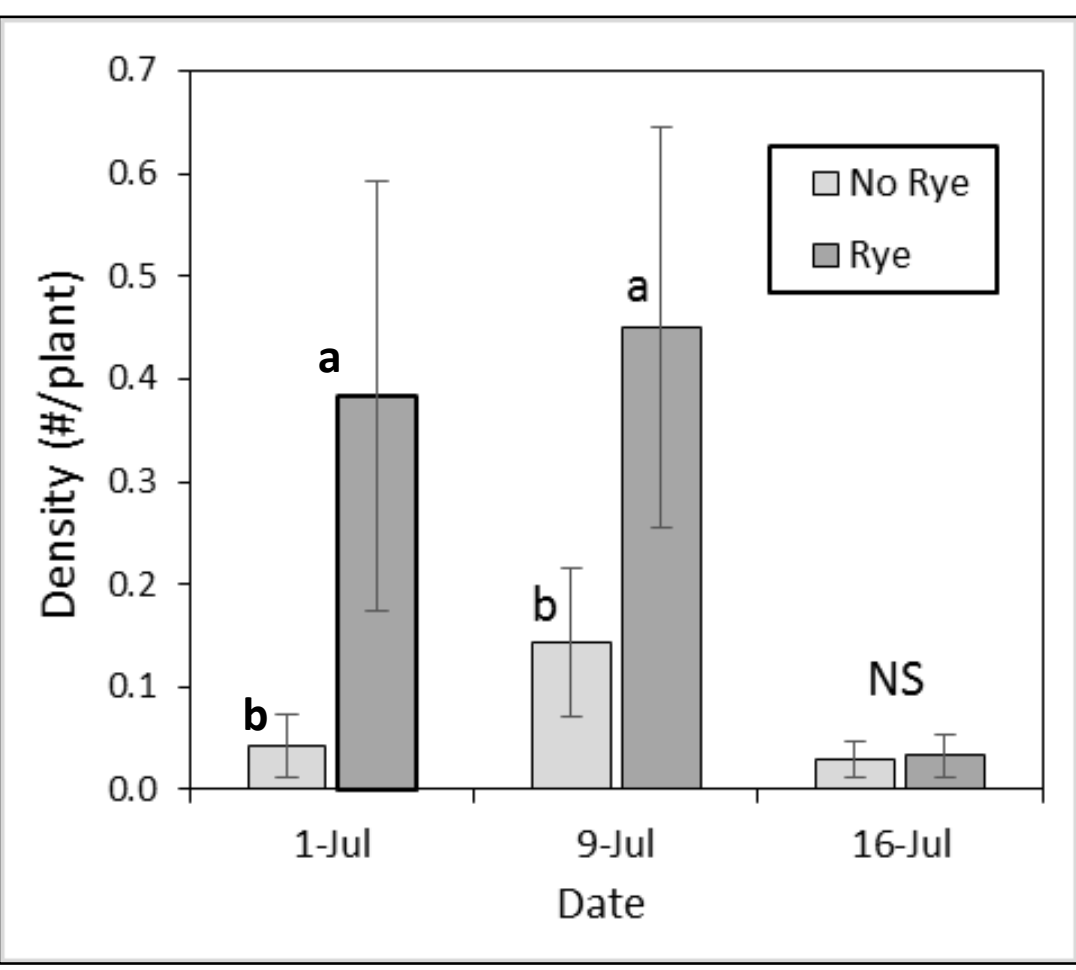

Figure 3. Main effect of rye cover crop on mean ( \pm se) density of tarnished plant bug, 2010. 